\title{
Testosterone Hormone Replacement Therapy: State-of-the-Art and Emerging Technologies
}

\author{
Marie-Laure Leichtnam, ${ }^{1,2}$ Hervé Rolland, ${ }^{2}$ Patrick Wüthrich, ${ }^{2}$ and Richard H. Guy ${ }^{1,3,4}$
}

Received December 7, 2005; accepted January 25, 2006

\begin{abstract}
In the human male, testosterone is the major circulating androgen. The clinical effects of androgen are numerous, and testosterone deficiency is associated with a number of clinical abnormalities. At present, a variety of preparations containing testosterone is available for the treatment of androgen deficiency. Ideally, those treatments have to produce and maintain physiologic serum concentrations of the hormone. This article reviews the current existing testosterone dosage forms on the market with their advantages and drawbacks and examines new and emerging technology developments concerning this therapy. In particular, the latest innovations in transdermal delivery are explored.
\end{abstract}

KEY WORDS: drug delivery; hormone replacement therapy; skin; testosterone; transdermal drug delivery.

\section{TESTOSTERONE: PRODUCTION AND DEFICIENCY (1)}

Testosterone (17ß-hydroxyandrost-4-en-3-one, MW 288) (Fig. 1) is the principal androgen synthesized in the testis, the ovary, and the adrenal cortex. This hormone plays an essential role in the development of the normal male and in the maintenance of many male characteristics, including muscle mass and strength, bone mass, libido, potency, and spermatogenesis. In women, testosterone is thought to influence pubertal development, sexual function, bone density, muscle mass, erythropoiesis, energy, cognitive function, and mood.

Cholesterol is the basic precursor that is transformed into pregnenolone and then via a variety of progestogens to androstenedione. This weak androgen is then reduced via 17ß-hydroxysteroid oxydoreductase to testosterone (Fig. 2). Biosynthesis takes place within the Leydig cells of the testis, stimulated by luteinizing hormone (LH). Ninety-eight percent of circulating testosterone is bound to albumin and sex hormone binding globulin (SHBG), leaving a small physiologically active free fraction.

In the human male, testosterone is the major circulating androgen. More than $95 \%$ of circulating testosterone is secreted by the testis, with a production rate of 6-7 mg per day (2). Circadian (i.e., almost daily) profiles of healthy young

\footnotetext{
${ }^{1}$ School of Pharmaceutical Sciences, Faculty of Sciences, University of Geneva, CH-1211 Geneva 4, Switzerland.

${ }^{2}$ Drug Delivery Research-Formulation Department, Technologie Servier, 45000 Orléans, France.

${ }^{3}$ Department of Pharmacy and Pharmacology, University of Bath, Claverton Down, Bath BA2 7AY, UK.

${ }^{4}$ To whom correspondence should be addressed. (e-mail: r.h.guy@ bath.ac.uk)
}

men are characterized by maximum levels of $\sim 25 \mathrm{nmol} / \mathrm{L}$ (720 ng/dL) occurring in the morning (around 0800 hours) and minimum levels of $\sim 15 \mathrm{nmol} / \mathrm{L}$ (430 ng/dL) occurring at night (around 2200 hours) (3) (Fig. 3). In the peripheral tissues (including skin and adipose tissue), circulating testosterone is enzymatically converted by $5 \alpha$-reductase and aromatase into its active metabolites, dehydrotestosterone (DHT) and estradiol (E2), respectively (Fig. 2). In normal men, the resulting plasma levels ratios of DHT/testosterone and E2/testosterone are $\sim 1: 10$ and 1:200, respectively.

In women, only small amounts of testosterone are synthesized in the ovary and adrenal. Healthy premenopausal women produce approximately $300 \mu \mathrm{g}$ of testosterone per day, about $5 \%$ of the daily production in men (3). Roughly half of the testosterone produced in women is derived from the ovaries, the other half from the adrenal glands, including the peripheral conversion of androgen precursors, androstenedione and dehydroepiandrosterone (DHEA), that are secreted from both organs (4). A significant cycling of androstenedione and testosterone in regularly ovulating women has been shown, with increases in the mid-third of the menstrual cycle and a subsequent rise in androstenedione in the late luteal phase.

Androgen deficiency, also known as hypogonadism (with testosterone levels less than $7.0 \mathrm{nmol} / \mathrm{L}$ or $200 \mathrm{ng} / \mathrm{dL}$ ) (5), results from the subnormal production of testosterone by the testis. Testicular failure (primary hypogonadism) may have a genetic or a developmental basis or may be acquired. Hypogonadotropic (secondary) hypogonadism may result from either acquired or congenital defects in pituitary or hypothalamic function (Table I).

The clinical manifestations of androgen deficiency depend on the age at onset and the severity and duration of the deficiency. In adult males, these manifestations may include reduced body hair, decreased muscle mass and strength, 


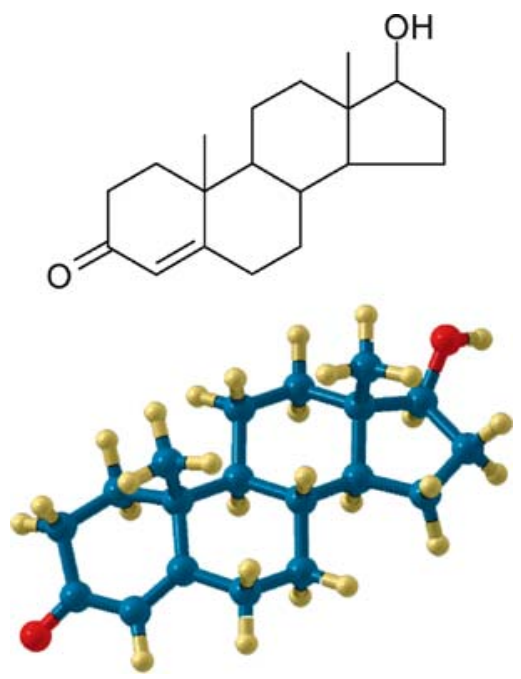

Fig. 1. Structure of testosterone.

increased fat mass and alterations in the distribution of fat, increased LDL and reduced HDL with risk of heart disease, decreased hematocrit, decreased libido, erectile dysfunction, infertility, osteoporosis, and depressed mood (6). It is now appreciated that hypogonadism may also accompany severe systemic illnesses such as cancer and AIDS (7) and that transient hypogonadism is frequently associated with profound emotional and physical stress, as occurs in response to surgery and burns. In case of androgen deficiency in early childhood, eunuchoidal proportions, lack of voice mutation, female distribution of secondary hair, anemia, and underdeveloped muscles and genitalia can be found, and spermatogenesis and sexual function are not initiated.

In women, following menopause, there is a drop in the blood production rate of not only estrogens but also of both the adrenal and ovarian androgens, namely, DHEA, DHEA sulfate, androstenedione, and testosterone. Postmenopausal women produce about $180 \mu \mathrm{g}$ of testosterone per day. Davis (8) described a clinical syndrome in women associated with a relative or absolute deficiency of circulating testosterone levels. This syndrome, called female androgen deficiency syndrome (FADS), is characterized by a decreased motivation or well-being, persistent fatigue, and low libido.

\section{THERAPEUTIC TESTOSTERONE REPLACEMENT}

\section{Indications}

Testosterone is principally used as a therapeutic agent for substitutional therapy for climacteric symptoms or for hypogonadism. It has also been employed to facilitate development of adult masculine characteristics when the adolescent process has been delayed (9).

\section{Hypogonadism}

Treatment of older men with low testosterone levels has long been a topic of discussion, but only recently, it became the object of controlled clinical studies (10). Unlike the female, in whom reproductive aging culminates in menopause and the cessation of ovarian function, reproductive aging in the male is a gradual process. There is a slow but continuous decline in average serum testosterone starting at 20-30 years (11). It has been estimated that approximately $50 \%$ of healthy men between the ages of 50 and 70 years have levels of bioavailable testosterone lower than the normal limit for men aged 20-40 years (12). This decrease occurs earlier and is more pronounced for free testosterone levels, decreasing from a mean value of about $0.5 \mathrm{nmol} / \mathrm{L}$ in young adults to approximately $0.2 \mathrm{nmol} / \mathrm{L}$ at the age of 80 (13). Whereas younger men have higher serum testosterone

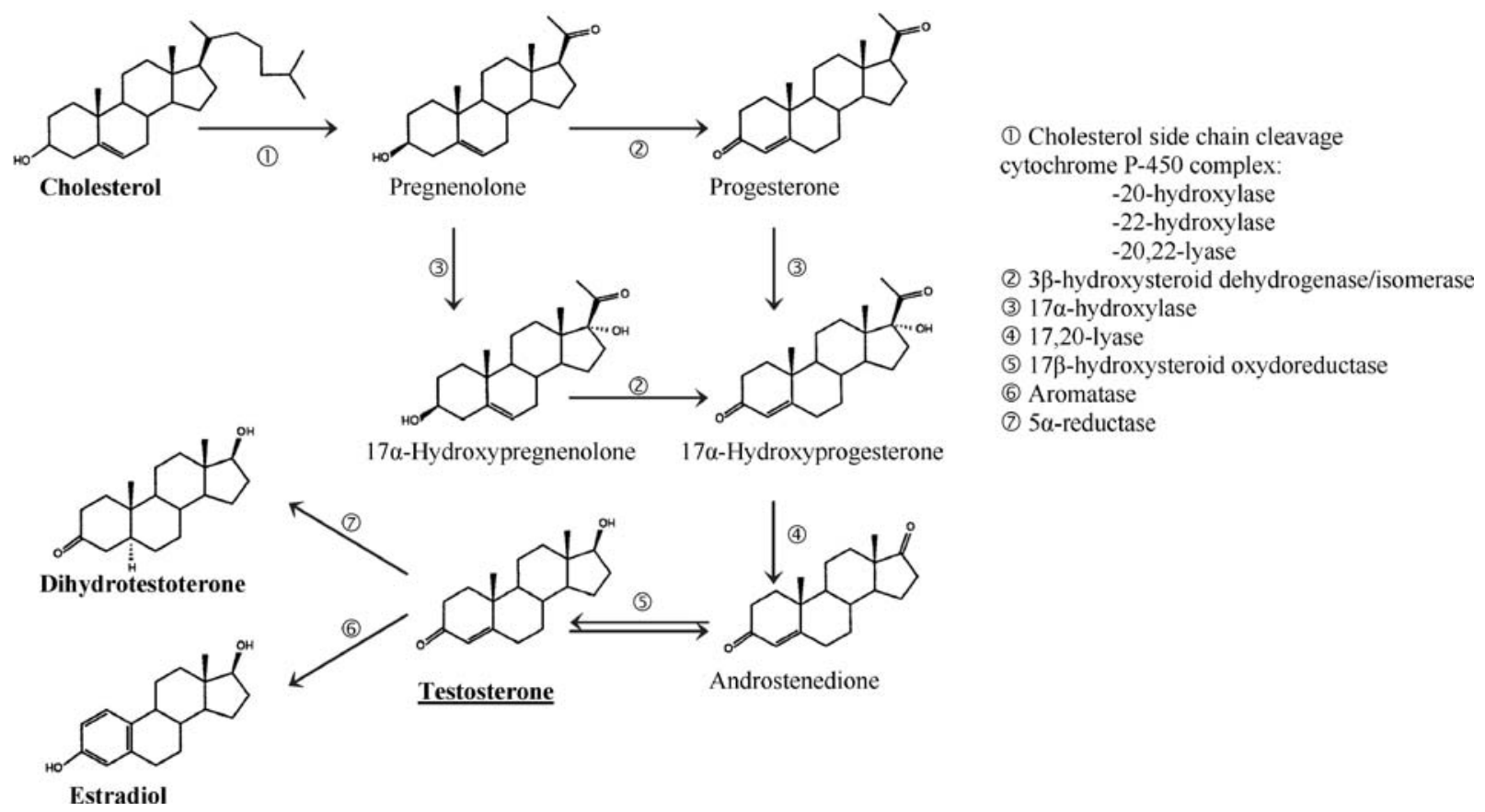

Fig. 2. Steroid biosynthesis. 


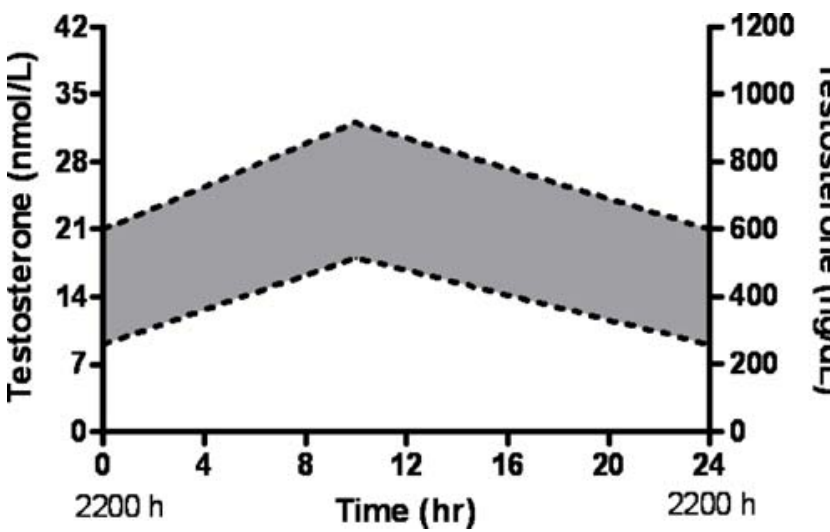

Fig. 3. Circadian variations of testosterone levels in young men (3).

levels in the mornings than in the evenings, this circadian rhythm is often lost in older men (14). There is still some controversy about hypogonadism being related to aging, but its incidence does indeed increase with age. Although there is no indication for testosterone medication in senescent men in general, when clinical symptoms require it, hypogonadal older patients should not be denied hormonal substitution. Efforts are being made to find the appropriate treatment regimen for such patients (5).

Testosterone replacement in hypogonadal men, both young and elderly, resulted in an increase in lean body mass, decrease in fat mass, improvement in sexual function and quality of life, and increase in bone mineral density (15-18). Sexual dysfunction is one of the most common complaints in men with hypogonadism. This, along with decreased energy, strength, and mood disorders, results in an overall decrease in quality of life scores. Therefore, testosterone replacement is beneficial and is indicated in men with hypogonadism.

\section{Cardiovascular Diseases}

Besides these "classical" therapeutic indications, testosterone could bring benefit heart and cardiovascular diseases, too. Until now, masculine hormones were considered deleterious for the cardiovascular system. Recent studies have shown that androgens, used in low doses, could have a beneficial effect on atherosclerosis and angina pectoris (19).

\section{Alzheimer's Disease}

Recently, it was shown in rats that hyperphosphorylation of the tau protein, implicated in Alzheimer's disease, was prevented by testosterone (20). Thereby, testosterone treatment in old men or testosterone and E2 treatment in menopausal women may potentially prevent or delay Alzheimer's disease. This hypothesis has to be tested in a clinical study.

\section{Contraception}

Another possible clinical application of testosterone is male contraception. Feedback inhibition of endogenous synthesis of the hormone is considered to induce infertility, but the results from clinical trials revealed that only about
$60 \%$ of the subjects treated with injections of testosterone esters show azoospermia or oligospermia (21). The objective, of course, is to totally inhibit spermatogenesis.

\section{Women}

Whereas current approaches for treating androgen deficiency in women are problematic, especially the doses to be delivered, research is underway to develop new testosterone delivery systems for women that will provide sustained physiological levels. Recently, Mazer (22) reviewed emerging treatments for testosterone deficiency in women. For women, testosterone therapy may be efficient when administered with estrogens in the treatment of menopause, estrogen replacement therapy affecting the total and free testosterone levels by increasing the levels of LH and SHBG. Androgens may also have a potential therapeutic role in the treatment of postmenopausal osteoporosis and fracture prevention. However, all the currently marketed androgen preparations are designed for replacement therapy for male hypogonadism, and although lower doses of testosterone seem appropriate for use in women, there is currently no information concerning the most appropriate dose or the optimal mode or route of testosterone delivery for women.

\section{Marketed Replacement Regimens}

A number of therapeutic alternatives are available to the clinician. The general goal of replacement therapy is to achieve physiological levels of testosterone (23), with a minimum of adverse effects and by the most convenient route of administration. Several options are available for androgen replacement in adult men, such as oral testosterone, intramuscular injections, subcutaneous implants, and

Table I. Low Testosterone Levels: Etiology

\begin{tabular}{ll}
\hline \multicolumn{1}{c}{ Men } & \multicolumn{1}{c}{ Women } \\
\hline $\begin{array}{l}\text { Congenital hypogonadism } \\
\text { Klinefelter's syndrome } \\
\text { (extra X chromosome) }\end{array}$ & $\begin{array}{c}\text { Premenopausal } \\
\text { bilateral oophorectomy } \\
\text { GnRH (LHRH) deficiency } \\
\text { (e.g., Kallmann's syndrome) }\end{array}$ \\
$\begin{array}{l}\text { Anorchism } \\
\text { Cryptorchidism }\end{array}$ & Premature ovarian failure \\
Acquired hypogonadism & Turner's syndrome \\
Chemotherapy & Adrenal disease \\
Glandular malformation & Pituitary disease \\
Anorchism & HIV infection \\
Head trauma that affects & Menopause \\
the hypothalamus & Oral contraceptives \\
Infection (meningitis, & Corticosteroids \\
syphilis, mumps) & \\
Isolated LH deficiency & Oral estrogen products \\
$\quad$ (e.g., fertile eunuch syndrome) & \\
Radiation & \\
Testicular trauma & \\
Tumors of the pituitary gland, & \\
hypothalamus, or testis & \\
Andropause & \\
\hline
\end{tabular}

$\mathrm{LH}=$ luteinizing hormone. 
transdermal therapy, each with its unique pharmacokinetic profile. It is generally agreed that androgen replacement therapy should deliver physiological amounts (3-10 mg/day) of testosterone, produce levels of testosterone, DHT, and E2 within normal physiological ranges, and mimic the circadian patterns of hormone levels found in healthy young men. It should have a good safety profile without adverse effects on the prostate gland, serum lipids, liver, or respiratory function. Finally, it should be "patient friendly."

\section{Oral Therapy}

Although orally administered testosterone is readily absorbed, it is ineffective because of extensive metabolism by the liver before reaching the systemic circulation. Thus, modifications of the testosterone molecule are required to render it orally active.

A number of different testosterone derivatives have been used with limited success. Alkylated androgens are more slowly metabolized than natural testosterone. Like testosterone, these androgens interact directly with androgen receptors. $17 \alpha$-Methyltestosterone and fluoxymesterone both achieve adequate androgenic effect but with variable clinical response (24) and unacceptable hepatotoxicity (25). Moreover, alkylated androgens may increase levels of low density lipoprotein cholesterol and profoundly suppress high density lipoprotein cholesterol levels because of their route of absorption and metabolism. Mesterolone, resembling $5 \alpha-$ dihydrotestosterone, a dihydrotestosterone derivative, seems safe but lacks androgenic potency (26).

At present, the only recommended orally active androgen is testosterone undecanoate (Fig. 4), formulated as an oleic acid solution in a soft gelatin capsule (Pantestone ${ }^{\circledR}$ ). This ester is absorbed into the lymphatic system, thereby avoiding first-pass metabolism. Testosterone undecanoate administered orally (40 mg, four to four times a day) produces short-lived peaks of a few hours duration, resulting in an irregular serum testosterone pattern during the course of the day. Pharmacokinetics was determined in several studies and demonstrated high intra- and interindividual variabilities in serum concentrations (27). For these reasons, this is not an ideal method of androgen replacement and is mainly reserved for individuals in whom other methods of testosterone administration are not successful (28).

\section{Buccal Therapy}

The oral mucosal route of administration is well established for various drugs such as nitroglycerin, which has been administered sublingually for over 100 years. Oral mucosal drug delivery offers several advantages over both injectable and enteral deliveries. Because the oral mucosa is

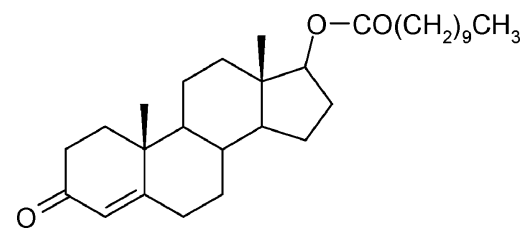

Fig. 4. Testosterone undecanoate. highly vascularized, absorbed drug directly enters the systemic circulation and avoids low gastric $\mathrm{pH}$, proteases, and first-pass hepatic degradation (29).

A limitation of oral mucosal delivery is that absorption of hydrophobic drugs may be more variable than with other routes. This drawback can be limited using bioadhesive systems, which can deliver physiologically relevant amounts of insoluble drugs such as testosterone, as a result of prolongation of the formulation residence time in the buccal cavity.

Recently, Columbia Laboratories marketed Striant ${ }^{\circledR}$, a sustained-release bioadhesive tablet containing $30 \mathrm{mg}$ of testosterone $(30,31)$. The tablet, which is $9 \mathrm{~mm}$ in diameter and adheres to the patient's gum, allows the slow release and absorption of testosterone through gum and cheek surfaces that are in contact with the tablet. Once applied, the tablet raises testosterone to normal physiologic levels for $12 \mathrm{~h}$. It is administered twice daily. This product utilizes both the bioadhesive delivery system (BDS) and the hydrating buccal technology platforms previously patented by the company. Pharmacologically inactive ingredients in Striant ${ }^{\circledR}$ are anhydrous lactose, carbomer 934P, hydroxypropylmethylcellulose, magnesium stearate, lactose monohydrate, polycarbophil, colloidal silicon dioxide, starch, and talc.

\section{Intramuscular Therapy}

The most commonly employed forms of androgen replacement therapy are intramuscular depot injections of the testosterone esters (Fig. 5) in the form of oily suspensions. Esterification increases the lipid solubility of testosterone and sustains its residence time. Following administration, the esters are released from the intramuscular site and stored in fat depots where they are cleaved to the parent compound. In general, the release rate decreases with the length of the chain and with increasing lipophilicity.

Testosterone enanthate (Androtardyl $\left.{ }^{\circledR}\right)$ (Fig. 5) is one of the most common testosterone derivatives used. This substance has a terminal half-life of 4.5 days; maximum concentrations are reached after $10 \mathrm{~h}$ following a single injection of $250 \mathrm{mg}$. Multiple-dose pharmacokinetics revealed an optimal injection interval of 2-3 weeks at this dose (27) (Fig. 6). Mackey et al. (32) evaluated the tolerability of deep intramuscular injections of testosterone enanthate in a castor oil vehicle over a period of 8 months. They concluded that deep intramuscular injection was generally safe but caused relatively frequent minor side effects, including pain and bleeding.

Testosterone cypionate (Depo-Testosterone ${ }^{\circledR}$ ) (Fig. 5) has similar pharmacokinetics to testosterone enanthate. As such, the cypionate does not provide any clear advantage over the enanthate ester. The recommended dose for testosterone cypionate is $200 \mathrm{mg}$ every 2 weeks (33).

Testosterone propionate $\left(\right.$ Testex $\left.^{\circledR}\right)$ (Fig. 5) has to be given every few days to achieve physiological testosterone levels. This ester has a terminal half-life of only $19 \mathrm{~h}$; after a single injection of $50 \mathrm{mg}$, the maximum concentration was reached after $14 \mathrm{~h}$. It is obvious that this substance requires more frequent injections: multiple-dose pharmacokinetics reveals optimal intervals of 2-3 days (27). Because of its pharmacokinetics, the propionate is not suitable for longterm treatment of hypogonadism. 

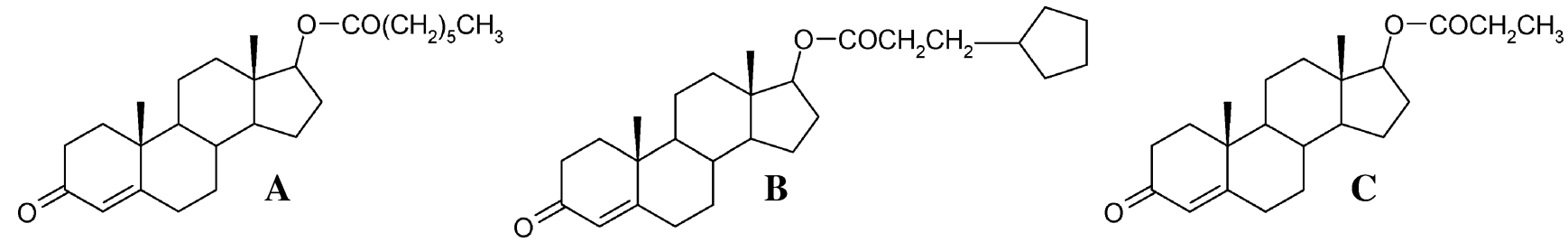

Fig. 5. Testosterone esters used in intramuscular therapy: (A) enanthate; (B) cypionate; (C) propionate.

Intramuscular therapy, although the most widely used delivery route, is not well accepted by patients. Because of the limited potency of testosterone and the low solubility of these testosterone esters, large amounts are required in a large volume (about 4-8 mL intramuscularly, depending on the vehicle). Moreover, in some patients, injections may be associated with local pain, bleeding, or bruising and with allergic reactions to sesame oil, the injection vehicle for testosterone enanthate, or to cottonseed oil, the vehicle for testosterone cypionate (34). Although self-administration is possible, most patients need the help of health care professionals for treatment, a requirement that is expensive and inconvenient.

These testosterone esters are quite effective in producing and maintaining normal virilization but have a number of undesirable features, such as the widely fluctuating serum testosterone levels (supraphysiological levels immediately after injection and subtherapeutic levels 10-14 days later) and the need for frequent injections $(26,35)$. A smoother profile could be obtained by using smaller doses more regularly, but increasing the frequency of injections is often unacceptable for patients. As a result, patients may experience side effects resulting from the supraphysiological testosterone plasma levels during the first few days after injection, such as mood disturbances and unfavorable changes in hematocrit and plasma lipid profile. Moreover, toward the end of the administration interval, plasma testosterone levels often drop below the normal range, which may result in the recurrence of hypogonadal symptoms (26).

Combinations of short- and long-acting esters are available to provide better pharmacokinetic profiles (e.g., Sus$\operatorname{tanon}^{\circledR}$ 250: testosterone propionate $30 \mathrm{mg}$, testosterone phenylpropionate $60 \mathrm{mg}$, testosterone isocaproate $60 \mathrm{mg}$, and testosterone decanoate $100 \mathrm{mg}$ ). In practice, however, the wide variation in testosterone levels still persists with these preparations. For treatment of male hypogonadism, there seems to be no advantage over the single-drug preparations (27).
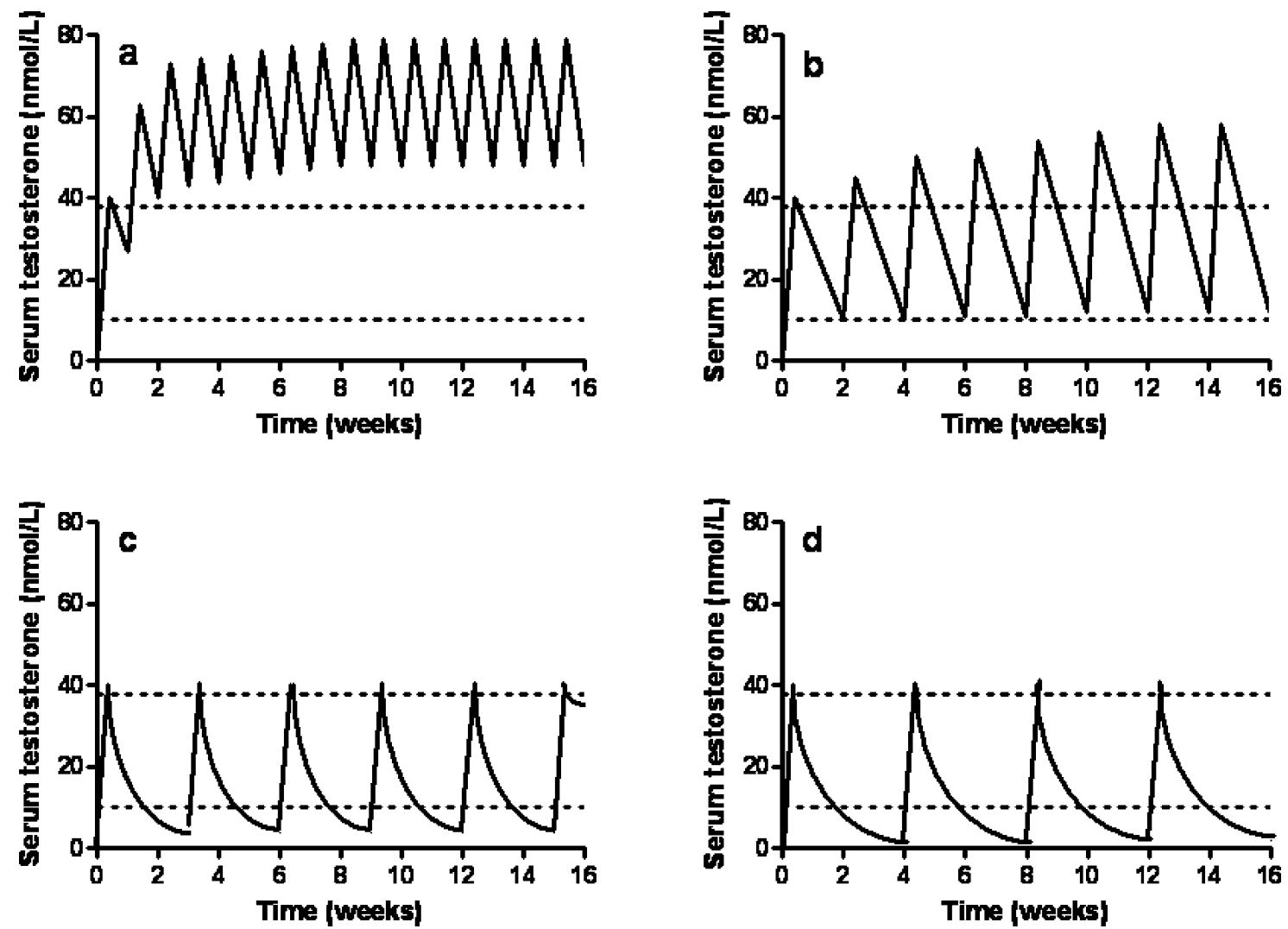

Fig. 6. Extrapolated serum testosterone concentrations after intramuscular injection of testosterone enanthate $250 \mathrm{mg}$ in men with hypogonadism: (a) every week; (b) 2 weeks; (c) 3 weeks; (d) 4 weeks (27). 


\section{Subcutaneous Implants}

Testosterone pellet implantation was one of the first modalities employed for clinical use and dates back to 1937. Traditional implants are defined as small sterile tablets consisting of the highly purified drug, usually compressed without excipients, and intended for subcutaneous insertion. The device has a high degree of hardness and virtually zero porosity. Because water does not penetrate the matrix, drug release occurs principally by surface dissolution. As a result of the inherently poor solubility of steroid drugs, this method provides an ideal form for depot medication (36). Oerton ${ }^{\circledR}$ pellets containing testosterone and marketed by Schering are one example of this technology.

Pellets/rods (Testopel pellets ${ }^{\circledR}$ ) can be produced by hightemperature molding and are available in two sizes, containing 100 or $200 \mathrm{mg}$ of crystalline steroid, with a length of 6 or $12 \mathrm{~mm}$ and a diameter of $4.5 \mathrm{~mm}$. Implanted subcutaneously every 4-6 months (37), under sterile conditions, they remain under the skin of the lower abdominal wall; other possible sites are upper thigh, deltoid, or gluteal muscle (38). Absorption occurs via erosion from the pellet surface following zero-order kinetics. A comparison between intramuscular injections of $250 \mathrm{mg}$ mixed testosterone esters at two weekly intervals, oral testosterone undecanoate (120 mg/day) and subcutaneous pellets $(6 \times 100 \mathrm{mg})$ in a prospective, randomized, crossover design indicated a constant elevation of testosterone in the pellet-treated patients that lasted for 4 months, whereas marked fluctuations were seen in the injection group (39). Subdermal testosterone implants produced a similar pattern to that obtained from intramuscular testosterone, but the profile of high initial peaks and decline thereafter extended over a much longer period of up to 6 months. Because of the longer time span, the patient hardly notices the slow swings of serum testosterone. Moreover, as surgical insertion is required only two to four times per year, patient acceptance is high.

Depot formulations of testosterone do suffer, however, from administration difficulties, as a minor surgical procedure is required. The possibility of extrusion, although rare, also exists (40). A review of 13 years of experience in subdermal testosterone implantation in 221 men showed limited adverse local effects (11\% of total 973 consecutive implants) such as extrusion, bleeding, and inflammations/infections. Effects were related to work activity and occurred more often in thinner men. Palpable subdermal fibrosis is infrequent (41).

\section{Transdermal Delivery}

Transdermal testosterone offers advantages over oral and intramuscular application in that both the first-pass metabolism in the liver after oral administration, requiring high testosterone doses, and potentially painful injections combined with supraphysiological testosterone serum concentrations are avoided. Moreover, the endogenous, circadian rhythm of testosterone secretion can be mimicked.

Testosterone is a good candidate for transdermal delivery (3). Steroids are hydrophobic, relatively small molecules, and highly potent (42). According to the literature $(43,44)$, the permeability of testosterone through human skin falls between $4.0 \times 10^{-4}$ and $2.2 \times 10^{-3} \mathrm{~cm} / \mathrm{h}$.
Previous experience with E2 patches has shown that the amount delivered to the blood stream by the transdermal system is small because the daily dose required is small. However, because a healthy adult male produces $3-11 \mathrm{mg}$ of testosterone per day, a high efficiency delivery system is needed to administer this steroid in an amount that is $50-100$ times the amount of E2 delivered via the skin (45). With the use of permeation enhancers, transdermal administration of testosterone at this level is possible. Numerous studies evaluated the percutaneous flux of testosterone using various enhancers such as liquid petrolatum, propylene glycol dipelargonate, Labrafac ${ }^{\circledR}$, Labrasol $^{\circledR}$ (mixture of mono-, di-, and triglycerides and mono- and difatty esters of polyethylene glycol) (46), 1-[2-(decylthio)ethyl] azacyclopentan-2-one (HPE-101) (47), or menthol (48).

The earlier topical androgen formulations (ointments), although convenient, carry the risk of transmission from one person to another, resulting in the androgenization of female partners (49). Percutacrine Androgenique Forte ${ }^{\circledR}$, formerly commercialized by Besins-Iovesco (Paris, France) was a topical ointment containing $10 \mathrm{mg} / \mathrm{mL}$ of testosterone. The low transcutaneous flux of testosterone from this formulation required the use of percutaneous enhancers: ether, alcohol, propylene glycol, and eucalyptus oil. It was administered by 30 drops daily on the abdomen (50). These solvents permeate skin, but without rate control and defined area of application, and could lead to excessive amounts of the drug in plasma. These problems have led to the design of fixed-area, easily applied, adhesive systems that control the rate and duration of testosterone input.

Because there are special principles to be followed in testosterone substitution in older men, such as a preference for the natural substance, reequilibration of physiological hormone levels, and the opportunity to stop treatment immediately as a result of possible development of prostatic disease), transdermal application represents an advantageous treatment modality for this age group (27) (Table II).

Scrotal Testosterone Patch (Testoderm ${ }^{\circledR}$ - Alza Pharmaceuticals, Mountain View, CA, USA). Testoderm ${ }^{\circledR}$ was the first testosterone transdermal therapeutic system (TTS) (51-53) introduced in 1995 and available in two sizes, 40 and $60 \mathrm{~cm}^{2}$. The patch is applied on the scrotum and delivers 4 or $6 \mathrm{mg}$ of testosterone, respectively, over a $24-\mathrm{h}$ period. This polymer matrix-type patch containing 10 or $15 \mathrm{mg}$ natural testosterone is composed of two layers: one is a soft, flexible, clothlike backing of polyethylene terephthalate; the other layer is a testosterone-containing film of ethylene-vinyl acetate (EVA) copolymer that gently adheres, at body temperature, to the scrotal skin surface without the need for a specific adhesive and modulates the permeation of testosterone.

In matrix systems, the solute is uniformly dispersed into an appropriate vehicle, usually a high-viscosity polymer. Such systems are easy and cheap to formulate, and they prolong the period of drug delivery. However, in most cases, the rate of drug release declines as a function of time. Although this may be disadvantageous when constant delivery is desired, the plasma profile thus produced may match with the body's natural rhythm for substances such as hormones. The matrix system for testosterone takesadvantage of this behavior and delivers testosterone in a circadian pattern; serum testosterone levels increase, then slowly decrease over $24 \mathrm{~h}$. The 
Table II. Transdermal Testosterone Replacement Options: Advantages, Disadvantages, and Doses Available

\begin{tabular}{|c|c|c|c|c|}
\hline Formulation & Tradename & Testosterone dose (mg/day) & Advantages & Disadvantages \\
\hline \multicolumn{5}{|l|}{ Gel } \\
\hline $\begin{array}{l}\text { Hydroalcoholic } \\
\text { preparation }\end{array}$ & Androgel $^{\circledR}$, Testim $^{\circledR}$ & $\begin{array}{l}5 \text { or } 10 \text {, delivery efficiency: } \\
\qquad 10-30 \%\end{array}$ & $\begin{array}{l}\text { No injections } \\
\text { Reliable delivery } \\
\text { No visible patch } \\
\text { Gel dries quickly } \\
\text { Good clinical response } \\
\text { Mimics circadian variation }\end{array}$ & $\begin{array}{l}\text { Expensive } \\
\text { Potential of testosterone } \\
\text { transfer to female } \\
\text { partner }\end{array}$ \\
\hline \multicolumn{5}{|l|}{ Scrotal patch } \\
\hline Drug-in-adhesive matrix & & & & \\
\hline $\begin{array}{l}\text { Active surface } \\
\text { area: } 40 \mathrm{~cm}^{2} \\
\text { Total surface } \\
\text { area: } 40 \mathrm{~cm}^{2}\end{array}$ & Testoderm $^{\circledR}$ & $\begin{array}{c}4 \text { or } 6 \text {, delivery efficiency: } \\
40 \%\end{array}$ & $\begin{array}{l}\text { No injections } \\
\text { Mimics circadian variation } \\
\text { Good clinical response }\end{array}$ & $\begin{array}{l}\text { Requires adequate scrotal } \\
\text { area and shaving } \\
\text { of scrotum } \\
\text { May cause irritation } \\
\text { Adhesion problems } \\
\text { Increased DHT levels }\end{array}$ \\
\hline \multicolumn{5}{|l|}{ Nonscrotal patch } \\
\hline $\begin{array}{l}\text { Liquid reservoir system } \\
\text { Active surface } \\
\text { area: } 7.5 \mathrm{~cm}^{2} \\
\text { Total surface } \\
\text { area: } 33.2 \mathrm{~cm}^{2}\end{array}$ & Androderm $^{\circledR}$ & $\begin{array}{l}5 \text { or } 10 \text {, delivery efficiency: } \\
20 \%\end{array}$ & $\begin{array}{l}\text { No injections } \\
\text { No need to shave } \\
\text { scrotal area } \\
\text { Good clinical response } \\
\text { Mimics circadian variation } \\
\text { Normal serum levels of } \\
\text { dihydrotestosterone }\end{array}$ & $\begin{array}{l}\text { High incidence of local } \\
\text { skin reactions }\end{array}$ \\
\hline
\end{tabular}

DHT $=$ dehydrotestosterone.

patch is rather thin $(0.14 \mathrm{~mm})$ and is applied each morning to the shaven scrotum where steroid absorption is highest (approximately 40 times that in the forearm) (54) and worn for $22-24 \mathrm{~h}$. The TTS delivers approximately $40 \%$ of its total testosterone content.

An initial pharmacokinetic study with this patch was performed by Findlay et al. (55). Testosterone levels rose within $1 \mathrm{~h}$ of application, peaked in $2-3 \mathrm{~h}$, and gradually declined over $22 \mathrm{~h}$. Levels decreased more abruptly during the last $2 \mathrm{~h}$ after the patch was removed. The nadir, seen at $22 \mathrm{~h}$ of application, was $60-80 \%$ of the peak value seen at 2-3 h (Fig. 7). This profile mimics the diurnal testosterone fluctuation in healthy men. The mean average testosterone concentration $22 \mathrm{~h}$ after application in this study was $135 \pm$ $38 \mathrm{ng} / \mathrm{dL}$ with placebo and $348 \pm 66,455 \pm 77$, and $624 \pm$ $65 \mathrm{ng} / \mathrm{dL}$ with the 5-, 10-, and 15-mg patches, respectively.

Numerous studies have shown the beneficial effects of Testoderm ${ }^{\circledR}$ on bone density $(18,56)$, energy and sexual function, fat mass, and lean body mass $(15,57)$. Moreover, Testoderm $^{\circledR}$ did not influence lipid profiles (58) contrary to that seen with more conventional administration of testosterone (59). No adverse effects on the prostate have been observed. Skin irritation is rare, and allergic contact dermatitis has not been seen (60).

After application of scrotal testosterone patches, supraphysiological dihydrotestosterone serum levels were measured (61) because of the presence of the enzyme $5 \alpha$ reductase in scrotal skin. Long-term side effects of high doses of DHT are unknown, but increased DHT concentrations have been measured in men with benign prostate hyperplasia. However, whether increased DHT concentrations are a cause of this hyperplasia or a consequence thereof is not yet resolved.
Although Testoderm ${ }^{\circledR}$ is preferred to intramuscular therapy, the fact that it is necessary to shave the scrotum to obtain good adhesion limits its acceptability. Moreover, these patches are not practical when the scrotal surface is inadequate.

Testoderm TTS for application to nonscrotal skin has also been marketed. The system comprises four layers: a flexible backing of transparent polyester/EVA copolymer film, a drug reservoir of testosterone in alcohol gelled with hydroxypropyl cellulose, an EVA copolymer membrane coated with a polyisobutylene adhesive formulation, and a protective liner of silicone-coated polyester which must be removed before application. The single patch delivers $5 \mathrm{mg}$ of testosterone per day. The incidence of itching at the application site was $12 \%$, and $3 \%$ of users experienced erythema. To

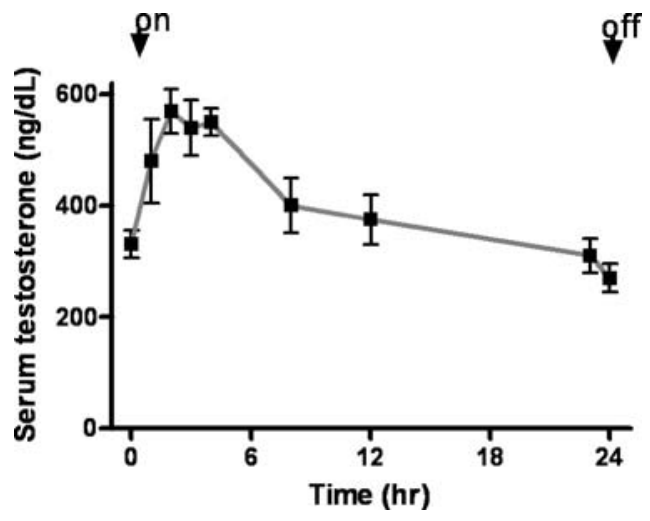

Fig. 7. Serum testosterone concentrations in five men with hypogonadism using a 10-mg scrotal patch (mean \pm SEM) (60). 


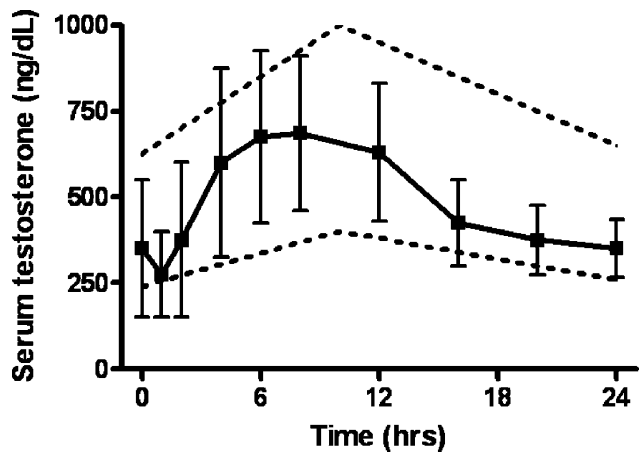

Fig. 8. Serum testosterone concentrations in hypogonadal men using a 5-mg nonscrotal testosterone patch (mean \pm SEM) (69).

date, however, this patch has suffered from adhesion problems, which have significantly limited its use $(62,63)$.

Nonscrotal Testosterone Patch (Androderm ${ }^{\circledR}$-Watson Pharma, Corona, CA, USA). The Androderm ${ }^{\circledR}$ testosterone transdermal delivery system was the first nonscrotal patch developed for physiological replacement therapy in hypogonadal men (3). This system was designed to overcome the pitfalls of the scrotal system. Introduced in 1996 in the United States, this testosterone transdermal system is available as a $37-$ or $74-\mathrm{cm}^{2}$ patch that delivers 2.5 or $5 \mathrm{mg}$ of testosterone per day (64). This patch comprises a liquid drug reservoir containing testosterone in a permeation-enhancing vehicle composed of water, ethyl alcohol, glycerin, glycerol monooleate, methyl laurate, and gelling agents, separated from the skin by a microporous membrane and surrounded by a peripheral adhesive system which affixes the system to the skin $(2,65)$.

Androderm ${ }^{\circledR}$ is designed to be applied everyday in the evening (between 8:00 p.m. and midnight) (66), rotating between skin sites on the back, abdomen, upper arms, and thighs. Its delivery efficiency is around $16 \%$. Most patients require two $2.5-\mathrm{mg}$ patches or one $5-\mathrm{mg}$ patch, which are bioequivalent (67) and provide physiological testosterone levels in over $90 \%$ of treated men (68). As $60 \%$ of the testosterone is delivered in the first $12 \mathrm{~h}$, the patches approximate the normal circadian rhythm of testosterone when applied at night (69) (Fig. 8). When two 2.5-mg patches were applied for $24 \mathrm{~h}, 60 \%$ of the drug was delivered in the first $12 \mathrm{~h}$ and $40 \%$ in the second 12 -h period. There was no accumulation of testosterone during continuous therapy. After system removal, serum testosterone levels decreased with a half-life of $70 \mathrm{~min}$ and returned to the hypogonadal range within $24 \mathrm{~h}$.

In addition, nonscrotal systems do not result in increased dihydrotestosterone levels seen with Testoderm ${ }^{\circledR}$ (70). The DHT/testosterone and E2/testosterone ratios after Androderm $^{\circledR}$ application were 1:10 and 1:200, respectively, values comparable with those found in eugonadal men.

Overall, with the nonscrotal patch, effects on sexual function and prostate volume seemed to match those achieved following conventional injection therapy (71). Improvements in sexual function, libido, energy level, mood, and lean body mass have been reported (72). Mean serum prostate-specific antigen levels and mean prostate volume remained within the normal range. Safety assessments have disclosed no clinically significant changes in lipid measures or serum chemistry.
In parallel with the development of testosterone transdermal systems, a number of conditions, in both males and females, where testosterone production is diminished and replacement therapy may be beneficial, have been investigated (73). For example, Androderm ${ }^{\circledR}$ has been evaluated for the treatment of adolescent hypogonadal males with $\beta$ thalassemia (74) and has been shown to induce increases in height and body weight. Genital development and an increased bone mineral density were also observed. To attain physiologic levels of serum testosterone in hypogonadal adolescent males, De Sanctis et al. (74) proposed modified application regimens of Androderm ${ }^{\circledR}$. For the treatment of 14-16 year-olds, a single $2.5-\mathrm{mg}$ patch should be applied at night and removed $12 \mathrm{~h}$ later, in the morning. For the 17-19 year-olds, a single 2.5-mg patch is applied nightly for $24 \mathrm{~h}$.

Local skin reactions are the most common adverse events reported for the nonscrotal testosterone transdermal system, with approximately $50 \%$ of men who participated in clinical trials reporting transient, mild to moderate erythema at the application site. Burnlike blister reactions occurred in $12 \%$ of men during the clinical trials, typically only once at a single application site (75). It seems that the permeation enhancers are responsible for this adverse reaction. Most reactions were associated with application of the systems over bony prominences or on parts of the body that could have been subject to prolonged pressure during sleep or sitting. Pretreatment of the application site with $0.1 \%$ triamcinolone acetonide cream decreased the skin reactions. However, despite the use of steroid, the significant skin reactions occurring in about one third of recipients lead to a high discontinuation rate $(10-15 \%)(76,77)$.

Testosterone Gels. The skin is nevertheless an attractive route for testosterone delivery, despite the drawbacks of the transdermal patches such as dose inflexibility, visibility, and skin irritation. Transdermal testosterone gel preparations have recently become available. Their performance is similar to that of the transdermal patches but with a much lower incidence of skin reactions.

Androgel $^{\circledR}$ (Solvay Pharmaceuticals, Marietta, GA, USA) is a $1 \%$ hydroalcoholic gel formulation. After a 10 -g application, at a single site (left arm/shoulders) or at four different separate sites (left and right arms/shoulders and left and right abdomen), the gel dried in less than $5 \mathrm{~min}$, and the stratum corneum served as a reservoir for the subsequent release of testosterone over several hours (78). The mean serum levels rose 2- to 3-fold above baseline at $0.5 \mathrm{~h}$ and 4 - to 5-fold

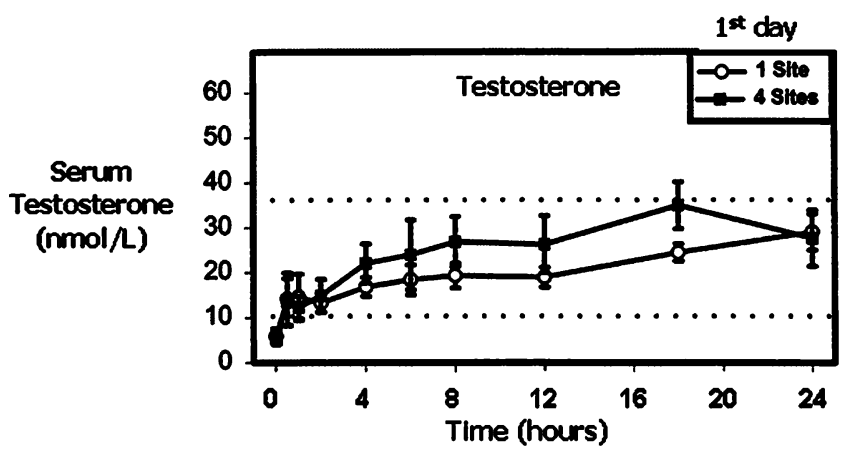

Fig. 9. Serum testosterone concentrations (mean \pm SEM) over $24 \mathrm{~h}$ after an initial application of $100 \mathrm{mg}$ of steroid in a $1 \%$ gel (78). 
after $24 \mathrm{~h}$ of application (reaching steady state) (Fig. 9). The testosterone concentration remained stable at 4- to 6.5-fold above baseline levels and returned to the pretreatment value 4 days after cessation of the treatment. About $9-14 \%$ of testosterone in the gel was bioavailable, and the serum dihydrotestosterone/testosterone ratio was normal.

Although no patients reported any major skin reaction in the initial pharmacokinetic study, with chronic treatment, about 5\% manifested mild irritation (79). This gel has been shown to improve muscle strength, lean body mass, sexual function, mood, and bone mineral density (80).

In early 2003, a new testosterone gel, Testim ${ }^{\circledR}$ (Auxilium Pharmaceuticals, Malvern, PA, USA) was launched in the United States. This 1\% hydroalcoholic formulation utilizes the permeation enhancer cyclopentadecanolide. A recent study found that hypogonadal patients treated with Testim ${ }^{\circledR}$ absorbed $30 \%$ more testosterone than those treated with Androgel ${ }^{\circledR}(81,82)$.

A major problem with conventional topical formulations is that the pharmacokinetics and pharmacodynamics are not reliably predictable because of poor control of the drug amount applied and of the area of application and because of the inter- and intraindividual variations in skin permeability. Moreover, topical androgen formulations are applied over large surface areas, and although there is little residue left on the skin, there remains a chance of person-toperson transmission via skin contact immediately after application (83). In a phase I study, Rolf et al. $(84,85)$ studied the pharmacokinetics of two doses of a transdermal hydroalcoholic gel containing $2.5 \%$ testosterone in gonadotropin-suppressed normal men. Physiological serum concentrations of testosterone were restored during the 10-day treatment period in the group of men applying $5 \mathrm{~g}$ testosterone gel. A physiological circadian profile was attained. E2 and DHT concentrations did not exceed normal values. Washing 10 min after gel application did not influence the absorption of testosterone and significantly reduced the risk of contamination of female partners or infants. In contrast, to achieve good absorption of testosterone following Androge ${ }^{\circledR}$ treatment, patients are instructed not to wash the skin for 5-6 h, and contamination has been observed in women after skin contact with men who had applied this formulation several hours earlier.

\section{Summary}

Various androgen replacement therapies for male hypogonadism are available (Table III). The choice of androgen preparation seems to be mainly determined by patient preference, with men opting for the mode of administration that delivers treatment in the most convenient way with minimum side effects. Until recently, intramuscular depot injections offered the most satisfactory combination of safety and efficacy, despite the fluctuations in serum testosterone levels that cause changes in sexual function, energy, and mood. On the other hand, because of limited effectiveness and a poor safety profile, currently available oral androgens are not recommended. The scrotal patch delivers testosterone at a controlled rate but has been associated with elevated levels of DHT and altered DHT/testosterone ratios. The nonscrotal transdermal delivery system achieves normal diurnal levels of testosterone, normal levels of DHT and E2, and normal ratios of DHT/testosterone and E2/testosterone. Local skin reactions are the most common adverse effect. These drawbacks can be avoided with gels that offer the same pharmacokinetic profile as the patches but carry the risk of transfer of testosterone to a partner. Nevertheless, transdermal delivery allows patients to self-administer their medication and to select among several anatomical sites for administration. For these reasons, this route of testosterone delivery represents a useful step toward ideal androgen replacement therapy.

Table III. Testosterone Dosage Forms

\begin{tabular}{|c|c|c|c|c|}
\hline Route & Drug & Dosage form & Dose & $\begin{array}{c}\text { Stage of } \\
\text { development }\end{array}$ \\
\hline \multirow[t]{3}{*}{ Oral } & Testosterone undecanoate & Capsules & $40 \mathrm{mg}, 2-4 /$ day & On market \\
\hline & $\begin{array}{l}\text { 17a-Alkylated androgens } \\
\text { (methyltestosterone and } \\
\text { fluoxymesterone) }\end{array}$ & Tablets & $10-50 \mathrm{mg} /$ day & On market \\
\hline & Testosterone cyclodextrins & Tablets & $7.5-15 \mathrm{mg} / \mathrm{day}$ & Clinical trials \\
\hline Buccal & Testosterone & Bioadhesive tablet & $30 \mathrm{mg}, 2 /$ day & On market \\
\hline \multirow[t]{6}{*}{ Intramuscular } & Testosterone enanthate & Oily suspension & $\begin{array}{l}200-250 \mathrm{mg} \text { every } \\
2-3 \text { weeks }\end{array}$ & On market \\
\hline & Testosterone cypionate & & $200 \mathrm{mg}$ every 2 weeks & On market \\
\hline & Testosterone propionate & & $50 \mathrm{mg}$ every $2-3$ days & On market \\
\hline & Testosterone undecanoate & Aqueous suspension & $\begin{array}{l}200-600 \mathrm{mg} \text { every } \\
2-3 \text { months }\end{array}$ & Clinical trials \\
\hline & Testosterone buciclate & & & \\
\hline & Testosterone microspheres & & $\begin{array}{l}615 \mathrm{mg} \text { every } \\
2-3 \text { months }\end{array}$ & Clinical trials \\
\hline Subcutaneous & Testosterone & Pellets & $\begin{array}{l}3-6(\times 200 \mathrm{mg}) \text { every } \\
6 \text { months }\end{array}$ & On market \\
\hline \multirow[t]{3}{*}{ Transdermal } & Testosterone & Gel & $1 \%, 10 \mathrm{~g} /$ day & On market \\
\hline & & Scrotal patch & $10 / 15 \mathrm{mg}, 1 /$ day & On market \\
\hline & & Nonscrotal patch & $\begin{array}{l}2.5 / 5 \mathrm{mg}, 2 \times 2.5 \text { or } \\
1 \times 5 / \text { day }\end{array}$ & On market \\
\hline
\end{tabular}



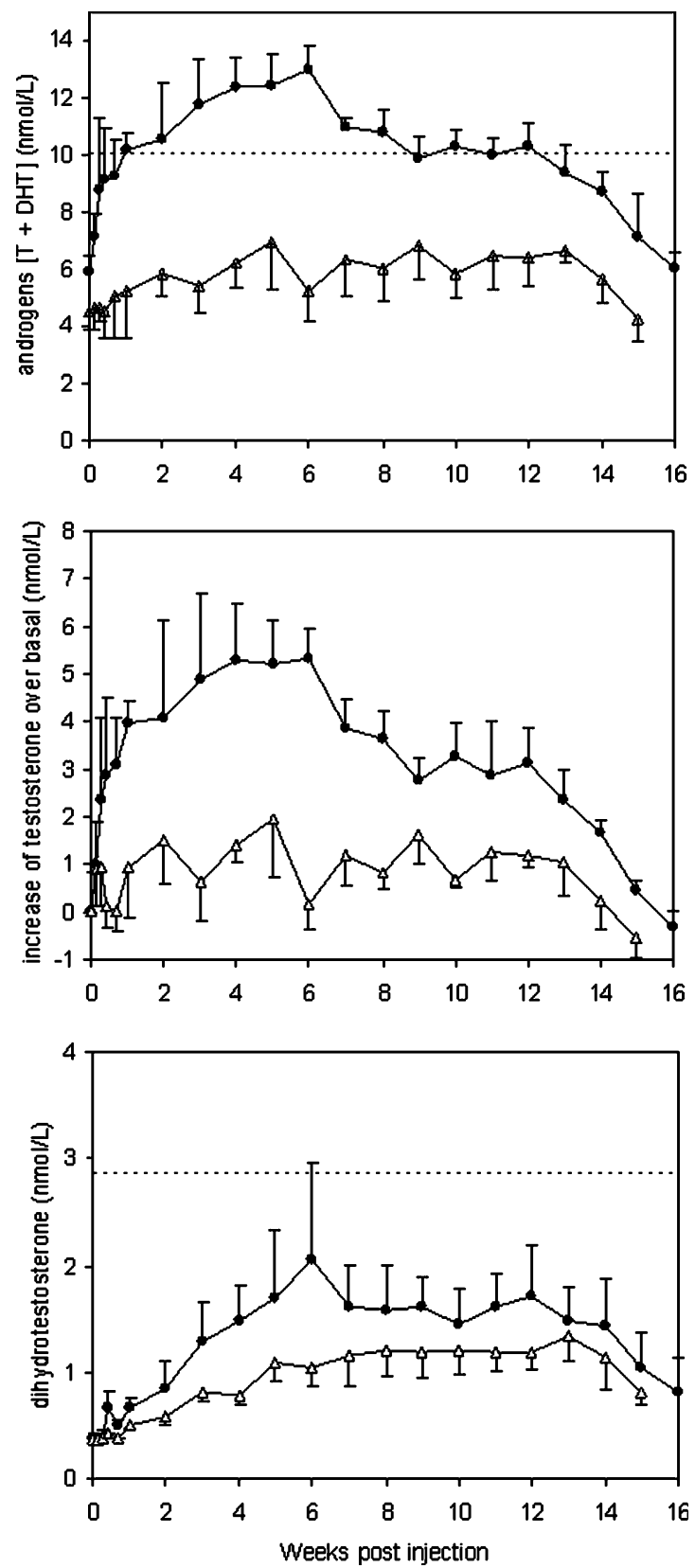

Fig. 10. Serum concentrations (mean \pm SEM) of androgens [sum of testosterone and dehydrotestosterone (DHT)] (upper panel), testosterone increase over baseline (middle panel), and DHT (lower panel) after single-dose intramuscular injections of $200 \mathrm{mg}$ (open triangles) or $600 \mathrm{mg}$ (filled circles) of testosterone buciclate to hypogonadal men. Broken line in the upper panel indicates the normal upper limit for DHT (91). After injection of $600 \mathrm{mg}$, androgens increased significantly and were maintained in the lower normal range for up to 12 weeks, with a $C_{\max }=13.1 \pm 0.9 \mathrm{nmol} / \mathrm{L}$ at $T_{\max }=6$ weeks.

\section{STATUS OF RESEARCH AND DEVELOPMENT PROJECTS}

Today, oral, parenteral, implantable, and transdermal testosterone dosage forms are available for clinical use, and others are under development. Each route of administration produces a distinct pharmacokinetic profile, the biological significance of which is not fully appreciated. Recently, a variety of additional methods for testosterone administration, including intramuscular therapy (86), nasal and pulmonary delivery, sublingual tablets (87), and topical aerosols $(88,89)$, have been investigated in an attempt to overcome some perceived drawbacks with existing approaches.

\section{Parenteral Delivery}

A major disadvantage of existing parenteral preparations is the wide interinjection fluctuations in the resulting testosterone levels. Both testosterone undecanoate (90) and testosterone buciclate (600 mg suspended in aqueous solution) (91) (Fig. 10) are currently undergoing evaluation and seem to offer longer-acting formulations and less variation in testosterone concentration.

Whereas already used orally, testosterone undecanoate revealed a significantly longer half-life compared with testosterone enanthate (92). This $17 \beta$-hydroxyl ester in castor oil $(250 \mathrm{mg} / \mathrm{mL})$ had $t_{1 / 2}=20.9 \pm 6.0$ days, with a maximal concentration of $19.3 \pm 2.1 \mathrm{nmol} / \mathrm{L}$ after $11.4 \pm 1.5$ days (93).
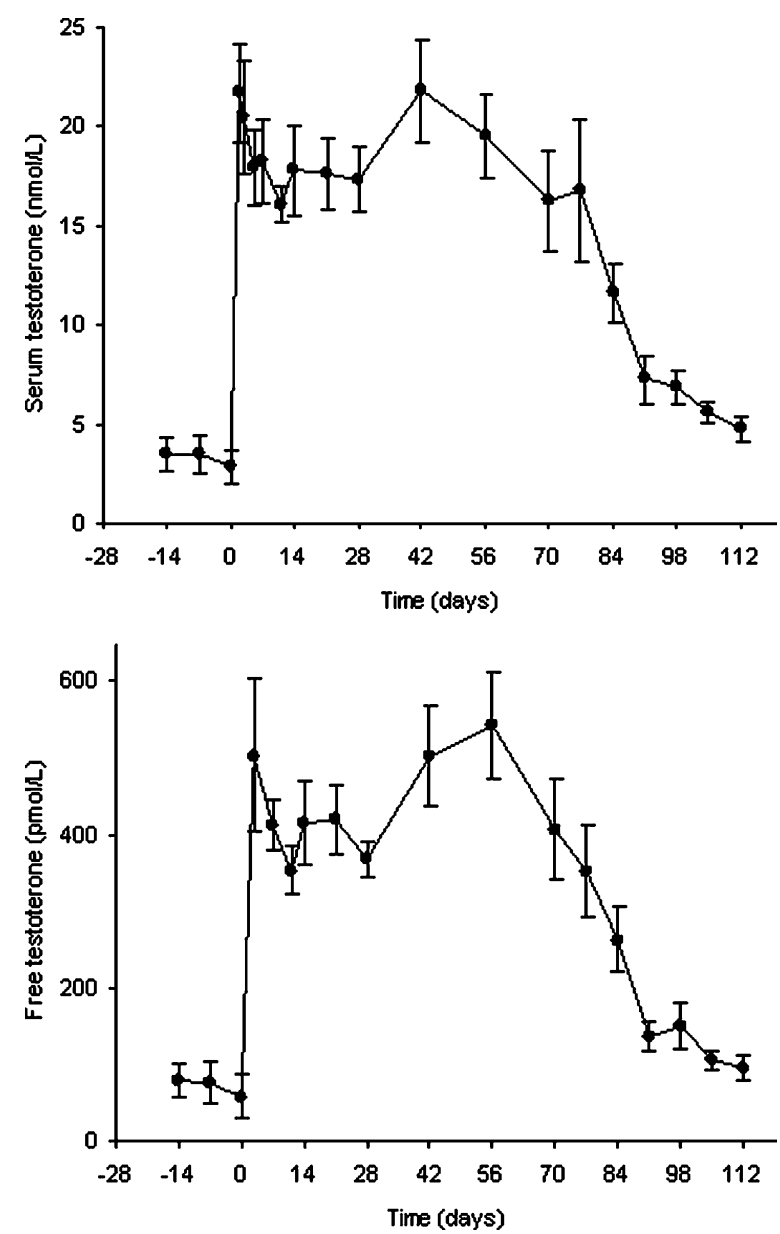

Fig. 11. Serum total (upper panel) and free testosterone (lower panel) levels before and after testosterone microcapsule administration in man (mean \pm SEM, $n=10)(96)$. 
The optimal injection interval was set between 6 and 8 weeks, but it seems that the intervals may even be extended to 12 weeks. Likewise, another ester, testosterone buciclate, showed a rather favorable pharmacokinetic profile (94). Further clinical studies showed a maximum concentration 9 weeks postinjection of $13.1 \pm 1.8 \mathrm{nmol} / \mathrm{L}$, the half-life being about 30 days. An injection of $1000 \mathrm{mg}$ testosterone buciclate maintained testosterone serum levels within the normal range up to week 16 (95).

Another way to control the absorption kinetics of testosterone involves microencapsulation. In this context, efforts have been underway to develop a long-acting depot formulation based on polylactide-polyglycolide microparticles. Testosterone $(315 \mathrm{mg})$ has been encapsulated in a matrix (Medisorb 85:15 lactide/glycolide copolymer) that biodegrades over about 150 days (96) (Fig. 11). The microcapsules provide reasonably uniform eugonadal levels of serum testosterone for 10-11 weeks in hypogonadal men, releasing $3 \mathrm{mg}$ of testosterone per day after a deep intramuscular injection, with approximately zero-order kinetics. No adverse local reactions, apart from pain at the site of injection, were noted. Whereas this formulation represents an attractive alternative to existing methods of androgen replacement, it is limited by the relatively large volume of diluent needed to inject the microcapsules and by the fact that the diurnal rhythm of serum testosterone secretion is not produced (97).

\section{Nasal Delivery}

In man, the area of the nasal mucosa is approximately $150 \mathrm{~cm}^{2}$, and there is a dense network of blood vessels offering the potential for efficient drug absorption while avoiding first-pass metabolism.

In an early study, a relatively simple nasal formulation of testosterone (methyl cellulose in distilled water) was tested in man. A very rapid and significant increase in plasma testosterone was observed $\left(T_{\max }=20 \mathrm{~min}\right)$, which returned to baseline after 120-180 min (98). This pharmacokinetic profile is comparable to that following oral administration of testosterone undecanoate; however, the duration of action is quite short, which means that repeated dosing would be necessary. In addition, testosterone is poorly soluble in water $(0.01 \mathrm{mg} /$ $\mathrm{mL}$ ), and an aqueous solution containing sufficient drug (3 mg) for human use is not feasible. Solubilizers commonly induce damage to the nasal mucosa; thus, their use is not recommended. It follows that nasal delivery of testosterone is unsuitable for long-term therapy and has not been pursued.

Further work, such as that of Hussain et al. (99), has therefore focused on the potential of the nasal route using a water-soluble prodrug, testosterone $17 \beta-N, N$-dimethylglycinate hydrochloride. The aqueous solubility of this derivative is more than $100 \mathrm{mg} / \mathrm{mL}$. The prodrug was almost immediately absorbed from the rat nasal cavity. The apparent half-life of prodrug disappearance is $10-20 \mathrm{~min}$, and the peak plasma concentration of testosterone was attained within 12-20 min (Fig. 12). The availability of the prodrug and testosterone was similar to those achieved after intravenous administration. Therefore, this prodrug could allow an aqueous formulation of testosterone well tolerated by the nasal cavity.

Increased absorption of testosterone is possible on solubilization of the drug and/or prolongation of the formu-

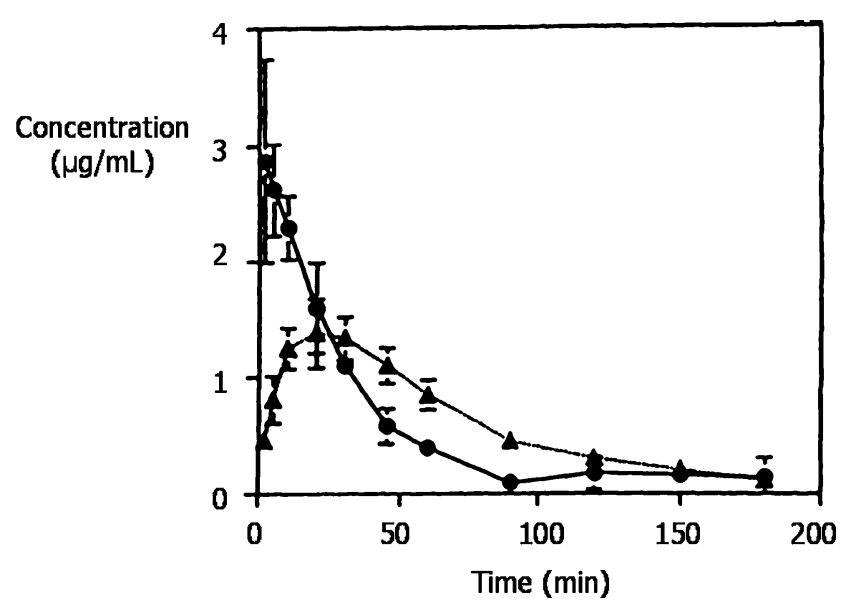

Fig. 12. Plasma concentrations of testosterone $17 \beta-N, N$-dimethylglycinate hydrochloride $(\bullet)$ and testosterone $(\mathbf{\Delta})$ after nasal administration of the prodrug at a dose equivalent to $25 \mathrm{mg} / \mathrm{kg}$ of testosterone in rat (mean \pm SEM, $n=3$ ) (99).

lation residence time in the nasal cavity. Ko et al. (100) achieved this objective using a new emulsion formulation containing Span 80 and neutralized soybean oil dispersed in phthalate buffer with Tween 80 . A dose of approximately 3.8 mg per rabbit was administered via a spray formulation. Electrostatic interactions between the emulsion droplets and the nasal mucosa prolonged the contact of drug with the membrane, enhancing drug absorption with a bioavailability of over $50 \%$ and $T_{\max }=20 \mathrm{~min}$.

\section{Pulmonary Delivery}

Local and systemic inhalation therapies can benefit from the controlled release of therapeutic agent, as might be achieved using biodegradable polymers. Slow release from an inhaled therapeutic particle can prolong the residence of an administered drug in the airways and can control the rate of the compound's appearance in the bloodstream. Pulmonary delivery also avoids first-pass metabolism by the liver, and this can improve patient compliance because dosing frequency is reduced. However, an effective, slow-release inhalation therapy requires that the lungs' natural clearance mechanism be suspended or avoided.

Recently, a new type of inhalation aerosol, characterized by particles of small mass density and large size [porous particles composed of 50:50 poly(lactic acid-co-glycolic acid, PLGA], has permitted the highly efficient delivery of testosterone in rats. Particles with mass densities less than $0.4 \mathrm{~g} / \mathrm{cm}^{3}$ and mean diameters exceeding $20 \mu \mathrm{m}$ were inspired deep into the lungs and escaped the lungs' natural clearance mechanisms. The systemic bioavailability was approximately ten times that from conventional inhaled particles (smaller, porous PLGA particles). Blood levels of testosterone remained above background levels for 12-24 h, confirming the slow release mechanism (the testosterone systemic $t_{1 / 2}$ being 10-20 $\mathrm{min}$ ). Testosterone bioavailability relative to subcutaneous injection was nearly doubled (101).

Aradigm's pulmonary technology provides aerosol generation and deep-lung dosing, suitable for either the rapid 
transfer of molecules into the bloodstream or localized delivery within the lung. The central element of their system is the $\mathrm{AERx}^{\circledR}$ Strip dosage form, which contains a disposable nozzle to insure superior aerosol performance each and every time the patient inhales medication. The devices utilizes a piston mechanism to expel the formulation from the dosage form. In a recent study, Davison et al. (102) determined the pharmacokinetics and safety of a single dose of orally inhaled testosterone via the $\mathrm{AERx}^{\circledR}$ System in 12 postmenopausal women stabilized on oral estrogen. Each patient inhaled a single dose of testosterone $(100,200$, or $300 \mu \mathrm{g})$. The $\mathrm{AERx}^{\circledR}$ System delivered aerosolized testosterone and achieved a pulse kinetic profile $\left(T_{\max }=1.4 \pm 0.5 \mathrm{~min}\right.$ at the maximal dose of $300 \mu \mathrm{g}$ ) with a rapid return to pretreatment levels, mimicking physiological hormonal secretion.

\section{Buccal Delivery}

Using bioadhesive tablets, testosterone, testosterone acetate, and testosterone propionate were better absorbed $(p<0.05)$ than less water-soluble esters. The mean absolute bioavailability of testosterone from the bioadhesive tablet was $14.1 \%$. Buccal administration results in plasma levels above $37 \mathrm{ng} / \mathrm{mL}$ for $15-24 \mathrm{~h}$ (103).

A novel bilayer mucoadhesive wax-film composite has been developed (104) containing Eudragit ${ }^{\circledR}$ and polycarbophil. In rabbits, the tested disk containing $4 \mathrm{mg}$ of testosterone and sodium lauryl sulfate as an enhancer produced zero-order release, with a $T_{\max }=200 \pm 35 \mathrm{~min}$ and a bioavailability of $50.2 \%$. Similar results were obtained in hypogonadal men receiving one $10-\mathrm{mg}$ buccal testosterone tablet per day. The delivery pattern was pulsatile, with a maximal testosterone concentration $30 \mathrm{~min}$ postadministration and a return to baseline in 4-6 h. Supraphysiological levels of testosterone were observed but lasted for only 1.5-4 h after the first administration. Accumulation of testosterone did not occur, even over 8 weeks of treatment (105) (Fig. 13).

Baisley et al. (106) determined the mean serum testosterone, free testosterone, and dihydrotestosterone concentrations showing circadian variation over $24 \mathrm{~h}$ following three doses of buccal-adhesive testosterone tablets $(10,20$, or
$30 \mathrm{mg}$ ) given daily over 10 days in healthy men. Peak testosterone concentrations were reached 8-9 h after dosing, and steady state was attained by day 5 . The average 24 -h concentrations for the three doses were within the normal range for eugonadal men, and the buccal tablets were well tolerated.

\section{Transdermal Delivery}

The transdermal route is unique insofar that it can provide physiological replacement of testosterone that mimics the serum level, circadian pattern, and metabolism observed in healthy young men, adolescent males, and premenopausal women. The new applications of the transdermal route involve amelioration of existing delivery systems (patches, gels) and the development of new approaches based on aerosols and sonophoresis.

\section{Patches}

It has been reported that ethanol/water (70:30) is the best cosolvent combination for transdermal testosterone delivery (107). A reservoir-type delivery system containing $1 \%(\mathrm{w} / \mathrm{v})$ dodecylamine as a skin permeation enhancer has been developed and allowed the testosterone permeation rate to be increased from 2.7 to $48 \mu \mathrm{g} \mathrm{cm}^{-2} \mathrm{~h}^{-1}$. This patch was formulated using an EVA membrane coated with a pressure-sensitive adhesive and showed comparable plasma concentration profiles in vivo when compared with Androderm ${ }^{\circledR}$ in rats (108).

\section{Hydrogel}

In a phase I study $(84,85)$, the pharmacokinetics of two doses of a transdermal hydroalcoholic gel containing $2.5 \%$ testosterone has been evaluated in gonadotropin-suppressed men. Physiological serum concentrations of testosterone were restored during the 10-day treatment period in the group applying 5.0-g testosterone gel. A physiological circadian profile was attained. E2 and DHT concentrations did not exceed normal values. Washing $10 \mathrm{~min}$ after gel application did not influence the resorption of testosterone
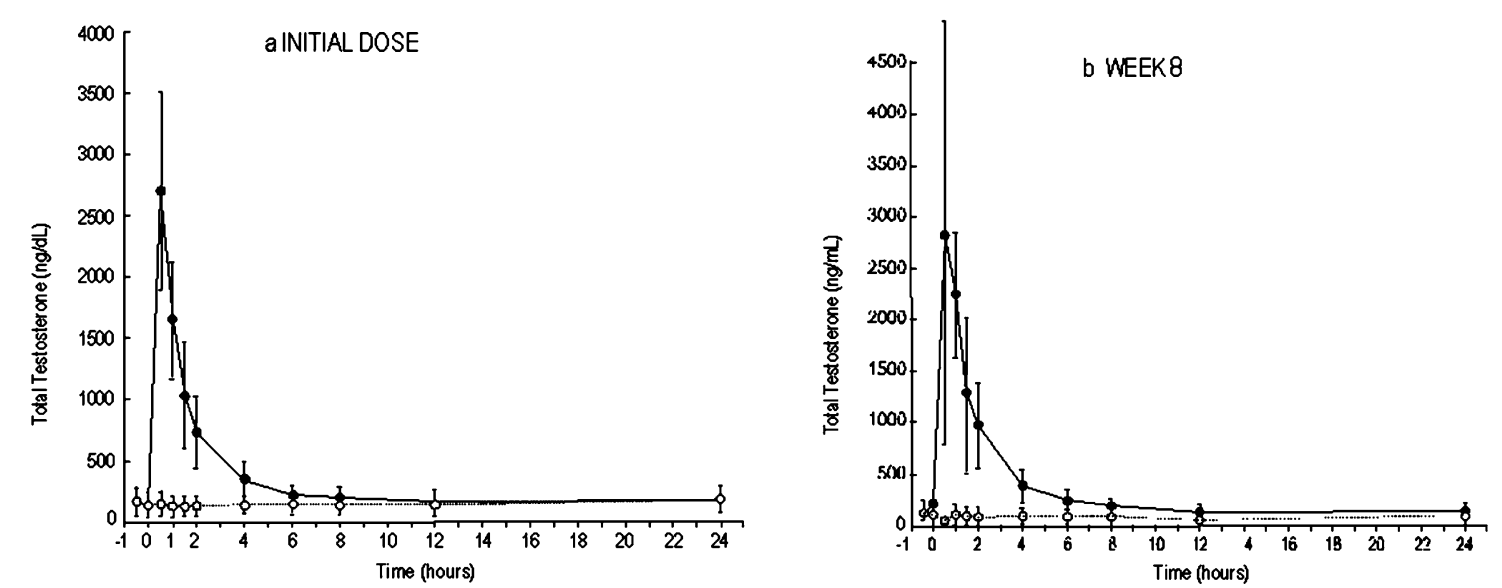

Fig. 13. Pharmacokinetics of mean (SD) total testosterone after administration of testosterone ( $\square$ ) or placebo (O) buccal tablets (105). 
and would presumably reduce the risk of contamination of female partners or infants. For comparison, to achieve good uptake of testosterone during Androgel ${ }^{\circledR}$ application, patients are instructed not to wash the skin for $5-6 \mathrm{~h}$, and contamination has been observed in women after skin contact with men who had applied Androgel ${ }^{\circledR}$ several hours earlier.

Recently (109), a polyvinyl alcohol and polyisobutylenebased soft hydrogel formulation has also been developed. This gel, which again used dodecylamine as an enhancer, formed a thin film on the skin 2-3 min after application and remained in a dried-film form for at least $24 \mathrm{~h}$.

Sepa $^{\circledR}$ (ethylene glycol condensed with decyl aldehyde) is a patented absorption enhancer (110). Sepa ${ }^{\circledR}$ is an acronym for "soft enhancement of percutaneous absorption," where soft refers to the reversibility of the skin effect. The permeation of testosterone from a gel containing this enhancer, Opterone ${ }^{\circledR}(1 \%$ testosterone $+5 \%$ Sepa $)$, has been evaluated. Application of $2.5 \mathrm{~g}$ of the gel resulted in the same area under the curve (AUC) as those achieved after administration of $5 \mathrm{~g}$ of Androgel ${ }^{\circledR}$. According to the company which has developed Opterone ${ }^{\circledR}$ (Macrochem Corp., Lexington, MA, USA), the gel differs from currently marketed products in that it needs to be applied to a significantly smaller surface area to achieve the same absorption, a property that is also expected to reduce the risk of transfer to children and partners (111).

\section{Metered Dose Transdermal Spray}

A metered dose transdermal system (MDTS $\left.{ }^{\circledR}\right)$ (Fig. 14) has been developed by Acrux, Ltd., West Melbourne, Australia. MDTS ${ }^{\circledR}$ technology has the potential to overcome some of the limitations with existing transdermal drug delivery systems, e.g., the irritation and adhesion problems associated with transdermal patches. The solution is formulated such that a volatile component evaporates, leaving a concentrated solution of drug in a vehicle that is rapidly taken up into the outer layers of the skin. Drug is then released from this reservoir in the skin over a prolonged period.

The liquid formulations used in the MDTS $^{\circledR}$ system incorporate the generally recognized as safe (GRAS) status skin penetration enhancers, octyl salicylate and padimate $\mathrm{O}$, which have been used for many years as sunscreen agents. This technology has also been used for other drugs, such as E2 (112) and granisetron (113), as well as testosterone (88).
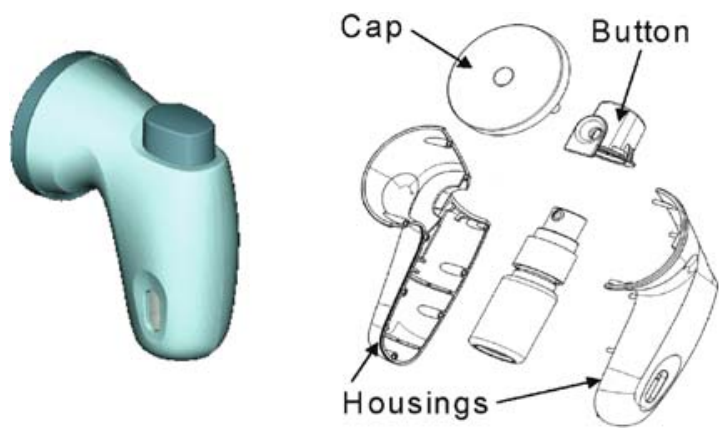

Fig. 14. $M D T S^{\circledR}$ applicator (Acrux, Inc.).

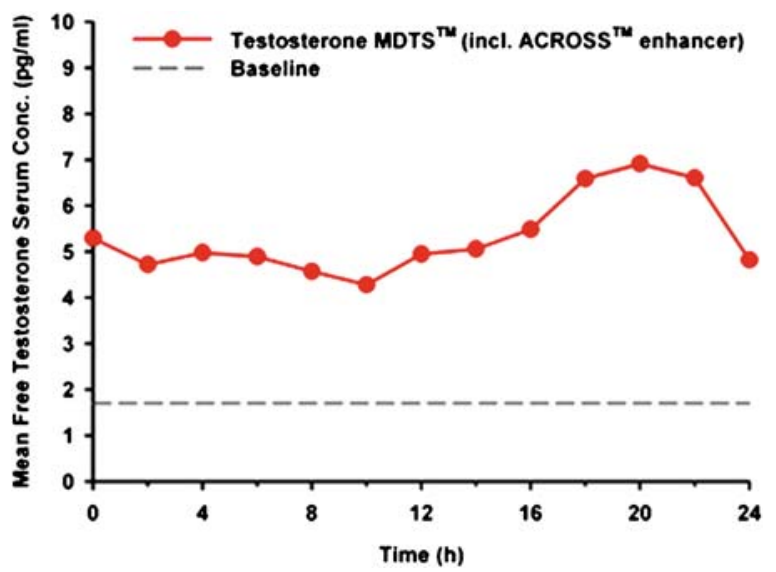

Fig. 15. Mean serum testosterone concentration after a testosterone MDTS $^{\circledR}$ application in women (Acrux, Inc.).

Rapid partitioning of testosterone and padimate $\mathrm{O}$ into swine skin occurred after $1 \mathrm{~min}$, with 70 and $60 \%$ of the applied dose $($ testosterone $=12 \% \mathrm{w} / \mathrm{v}$; padimate $\mathrm{O}=8 \% \mathrm{v} / \mathrm{v}$ ) remaining in the skin after the unabsorbed formulation was removed by rinsing with absolute ethanol. The cumulative amount of testosterone at $24 \mathrm{~h}$ penetrating across snake skin was significantly enhanced by up to 6-fold for octyl salicylate, by 3-fold for oleic acid and Azone, and by 2-fold for padimate $\mathrm{O}$ compared with control sample. A testosterone MDTS $^{\circledR}$ is being evaluated clinically for the treatment of female androgen insufficiency (Fig. 15).

\section{Ultrasound-Enhanced Transdermal Transport}

The application of low-frequency $(20-100 \mathrm{kHz})$ ultrasound can significantly enhance the transdermal transport of drugs (114). This technique, used originally in physiotherapy and sports medicine, has now been extended to transdermal drug delivery and glucose monitoring (115-117).

It seems that ultrasound, via a mechanism based on cavitation (118), is able to significantly permeabilize the skin. The duration of exposure can be quite short, with an effect lasting up to more than $12 \mathrm{~h}$. Preliminary studies have shown that ultrasound can permit improved testosterone delivery across the skin (44).

\section{CONCLUSION}

Testosterone deficiency is associated with adverse effects on body composition, bone density, sexual function, and mood and may also increase cardiovascular risk. Numerous studies have demonstrated the benefits of testosterone replacement in overtly hypogonadal men. There are several possible administration routes for testosterone replacement. Each approach has advantages and drawbacks, and the choice of the method of replacement will often be determined by patient preference. Although new developments are promising, it seems that, among the available treatments, only transdermal delivery has provided pharmacokinetic behavior that most closely mimics the natural diurnal variations in man. 


\section{REFERENCES}

1. J. D. Wilson. Androgens. In A. G. Gilman, T. Palmer, and A. S. Nies (eds.), Goodman and Gilman's the Pharmacological Basis of Therapeutics, 8th ed., Pergamon Press, New York, 1990, pp. $1413-1430$.

2. W. A. Meikle, J. F. Moellmer, K. G. Tolman, S. W. Sanders, and W. D. Odell. Enhanced transdermal delivery of testosterone across no scrotal skin produces physiological concentrations of testosterone and its metabolites in hypogonadal men. J. Clin. Endocrinol. Metab. 74:623-628 (1992).

3. N. A. Mazer, W. E. Heiber, J. F. Moellmer, W. A. Meikle, S. W. Sanders, K. G. Tollman, and W. D. Odell. Enhanced transdermal delivery of testosterone: a new physiological approach for androgen replacement in hypogonadal men. J. Control. Release 19:347-362 (1992).

4. G. E. Abraham. Ovarian and adrenal contribution to peripheral androgens during the menstrual cycle. J. Clin. Endocrinol. Metab. 39:340-346 (1974).

5. S. Bhasin, C. J. Bagatell, W. J. Bremner, S. R. Plymate, J. L. Tenover, S. G. Korenman, and E. Nieschlag. Therapeutic perspective - issues in testosterone replacement in older men. J. Clin. Endocrinol. Metab. 83:3435-3448 (1998).

6. S. Basaria and A. S. Dobs. Hypogonadism and testosterone replacement in elderly men. Am. J. Med. 110:563-572 (2001).

7. A. S. Dobs, M. A Dempsey, P. W. Ladenson, and B. F. Polk. Endocrine disorders in men infected with human immunodeficiency virus. Am. J. Med. 84:611-616 (1988).

8. S. Davis. Testosterone deficiency in women. J. Reprod. Med. 46:291-296 (2001)

9. A. R. Gennaro. Remington: The Science and Practice of Pharmacy, 20th ed., Lippincott Williams and Wilkins, Philadelphia, 2000, p. 1391.

10. A. Gray, H. A. Feldman, J. B. McKinlay, and C. Longscope. Age, disease, and changing sex hormone in the middle-aged men: results of the Massachusetts male aging study. J. Clin. Endocrinol. Metab. 73:1016-1025 (1991).

11. A. Gray, J. A. Belin, J. B. McKinlay, and C. Longcope. An examination of research design effects on the association of testosterone and male aging: the results of a meta-analysis. J. Clin. Epidemiol. 44:671-684 (1991).

12. F. E. Purifoy, L. H. Koopmans, and D. M. Mayes. Age differences in serum androgen levels in normal adult males. Hum. Biol. 53:499-511 (1981).

13. A. Vermeulen. Androgens and male senescence. In E. Nieschlag and H. M. Behre (eds.), Testosterone-Action, Deficiency, Substitution, Springer-Verlag, Berlin, 1990, pp. 261-274.

14. W. J. Bremner, M. V. Vitiello, and P. N. Prinz. Loss of circadian rhythmicity in blood testosterone levels with aging in normal men. J. Clin. Endocrinol. Metab. 56:1278-1281 (1983).

15. P. J. Snyder, H. Peachey, P. Hannoush, J. A. Berlin, L. Loh, D. A. Lenrow, J. H. Holmes, A. Dlewati, J. Santanna, C. J. Rosen, and B. L. Strom. Effect of testosterone treatment on body composition and muscle strength in men over 65 years of age. J. Clin. Endocrinol. Metab. 84:2647-2653 (1999).

16. L. Katznelson, J. J. S Finkelstein, D. S. Schoenfeld, D. I. Rosenthal, E. J. Anderson, and A. Klibanski. Increase in bone density and lean body mass during testosterone administration in men with acquired hypogonadism. J. Clin. Endocrinol. Metab. 81:4358-4365 (1996).

17. H. M. Behre, S. Kleish, E. Leifke, T. M. Link, and E. Nieschlag. Long-term effect of testosterone therapy in bone mineral density in hypogonadal men. J. Clin. Endocrinol. Metab. 82:2386-2390 (1997).

18. P. J. Snyder, H. Peachey, P. Hannoush, J. A. Berlin, L. Loh, J. H. Holmes, A. Dlewati, J. Staley, J. Santanna, S. C. Kapoor, M. F. Attie, J. G. Haddad Jr., and B. L. Strom. Effect of testosterone treatment on bone mineral density in men over 65 years of age. J. Clin. Endocrinol. Metab. 84:1966-1972 (1999).

19. K. M. English, R. P. Steeds, T. Hugh Jones, M. J. Diver, and K. S. Channer. Low-dose transdermal testosterone therapy improves angina threshold in men with chronic stable angina. Circulation 102:1906-1911 (2000).
20. S. C. Papasozomenos and A. Shanavas. Testosterone prevents the heat shock-induced overactivation of glycogen synthase kinase- 3 beta but not of cyclin-dependent kinase 5 and c-Jun NH2-terminal kinase and concomitantly abolishes hyperphosphorylation of tau: implications for Alzheimer's disease. Proc. Natl. Acad. Sci. USA 99:1140-1145 (2002).

21. J. S. Finkelstein, R. W. Whitcomb, L. S. O'Dea, C. Longcopes, D. A. Schoenfeld, and W. F. Crowly Jr. Sex steroid control of gonadotropin secretion in the human male. I. Effects of testosterone administration in normal and gonadotropin releasing hormone deficient men. J. Clin. Endocrinol. Metab. 73:609-620 (1991).

22. N. A. Mazer. Testosterone deficiency in women: aetiologies, diagnosis and emerging treatments. Int. J. Fert. Women's Med. 47:77-86 (2002).

23. E. Nieschlag, C. Wang, D. J. Handelsman, R. S. Swerdloff, F. Wu, N. Einer-Jensen and G. Waites. Guidelines for the Use of Androgens, World Health Organization, Geneva, 1992.

24. A. Morales, B. Johnston, J. W. P. Heaton, and A. Clark. Oral androgens in the treatment of hypogonadal impotent men. J. Urol. 152:1115-1118 (1994).

25. F. C. Wu. Steroidogenesis and androgen use and abuse. Bailliere's Clin. Endocrinol. Metab. 6:403-737 (1992).

26. E. Nieschlag and H. M. Behre. Pharmacology and clinical uses of testosterone. In E. Nieschlag and H. M. Behre (eds.), Testosterone-Action, Deficiency, Substitution, 2nd ed., SpringerVerlag, Berlin, 1998, pp. 293-328.

27. H. M. Behre and E. Nieschlag. Comparative pharmacokinetics of testosterone esters. In E. Nieschlag and H. M. Behre (eds.), Testosterone-Action, Deficiency, Substitution, 2nd ed., Springer- Verlag, Berlin, 1998, pp. 329-348.

28. S. Howell and S. Shalet. Testosterone deficiency and replacement. Horm. Res. 56(Suppl. 1):86-92 (2001).

29. H. Zhang, J. Zhang, and J. B. Streisand. Oral mucosal drug delivery-clinical pharmacokinetics and therapeutic applications. Clin. Pharmacokinet. 41:661-680 (2002).

30. J. R. Robinson. Bioadhesive compositions and methods of treatment therewith. US Patent 4,615,697 (1986)

31. W. J. Bologna, H. L. Levine, P. Cartier, and D. de Ziegler. Bioadhesive progressive hydration tablets and methods of making and using the same. US Patent 6,248,358 (2001).

32. M. A. Mackey, A. J. Conway, and D. J. Handelsman Tolerability of intramuscular injections of testosterone ester in oil vehicle. Hum. Reprod. 10:862-865 (1995).

33. H. R. Nankin. Hormone kinetics after intramuscular testosterone cypionate. Fertil. Steril. 47:1004-1009 (1987).

34. C. Wang and R. S. Swerdloff. Androgen replacement therapy. In C. W. Bradin (ed.), Current Therapy in Endocrinology and Metabolism, CV Mosby, St Louis, MO, 1997, pp. 331-337.

35. P. J. Snyder and D. A. Lawrence. Treatment of male hypogonadism with testosterone enanthate. J. Clin. Endocrinol. Metab. 51:1335-1339 (1980).

36. The United States Pharmacopoeia, XX, The United States Pharmacopeial Convention, Rockville, 1980, p. 1027.

37. D. J. Handelsman. Clinical pharmacology of testosterone pellet implants. In E. Nieschlag and H. M. Behre (eds.), Testosterone-Action, Deficiency, Substitution, 2nd ed., Springer-Verlag, Berlin, 1998, pp. 349-364.

38. H. R. Bhagat and R. S. Langer. Implants and implantation therapy. In J. Swarbrick and J. C. Boylan (eds.), Encyclopedia of Pharmaceutical Technology, Vol. 8, Marcel Dekker, New York, 1993, pp. 53-82.

39. A. J. Conway, L. M. Boylan, C. Howe, G. Ross, and D. J. Handelsman. Randomized clinical trial of testosterone replacement therapy in hypogonadal men. Int. J. Androl. 11:247-264 (1988).

40. F. Jockenhovel, E. Vogel, M. Kreutzer, W. Reinhaardt, S. Lederbogen, and D. Reinwein. Pharmacokinetics and pharmacodynamics of subcutaneous testosterone implants in hypogonadal men. Clin. Endocrinol. (Oxf.) 45:61-71 (1996).

41. D. J. Handelsman, M. A. Mackey, C. Howe, L. Turner, and A. J. Conway. An analysis of testosterone implants for androgen replacement therapy. Clin. Endocrinol. (Oxf.) 47:311-316 (1997).

42. R. Sitruk-Ware. Transdermal delivery of steroids. Contraception 39:1-20 (1989). 
43. R. J. Scheuplein, I. H. Blank, G. J. Brauner, and D. J. MacFarlane. Percutaneous absorption of steroids. J. Invest. Dermatol. 52:63-70 (1969).

44. S. Mitragotri, D. A. Edwards, D. Blankschtein, and R. Langer. A mechanistic study of ultrasonically-enhanced transdermal drug delivery. J. Pharm. Sci. 84:697-706 (1995).

45. M. S. Powers, L. Schenkel, P. E. Darley, W. R. Good, J. C. Balestra, and V. A. Place. Pharmacokinetics and pharmacodynamics of transdermal dosage forms of 17ß-estradiol: comparison with conventional oral estrogens used for hormone replacement. Am. J. Obstet. Gynecol. 152:1099-1106 (1985).

46. F. P. Bonina, V. Carelli, G. Di Colo, L. Montenegro, and E. Nannipieri. Vehicle effects on in vitro skin permeation of and stratum corneum affinity for model drugs caffeine and testosterone. Int. J. Pharm. 100:41-47 (1993).

47. T. Yano, N. Higo, K. Fukuda, M. Tsuji, K. Noda, and M. Otagiri. Further evaluation of a new penetration enhancer (HPE 101). J. Pharm. Pharmacol. 45:775-778 (1993).

48. Y. Kaplun-Frischoff and E. Touitou. Testosterone skin permeation enhancement by menthol through formation of eutectic with drug and interaction with skin lipids. J. Pharm. Sci. 86:1394-1399 (1997).

49. D. Delanoe, B. Fougeyrollas, L. Meyer, and P. Thonneau. Androgenisation of female partners of men on medroxyprogesterone acetate/percutaneous testosterone contraception. Lancet 1:276 (1984).

50. J. C. Soufir, P. Jouannet, J. Marson, and A. Soumah. Reversible inhibition of sperm production and gonadotropin secretion in men following combined oral medroxyprogesterone acetate and percutaneous testosterone treatment. Acta Endocrinol. 102:625-632 (1983).

51. T. Higuchi and A. Hussain. Device consisting of copolymer having acetoxy groups for delivery of drugs. US Patent 4,144,317 (1979).

52. P. S. Campell and J. B. Eckenhoff. Transdermal therapeutic system having improved delivery characteristic. US Patent 4,704,282 (1987).

53. P. S. Campell, J. B. Eckenhoff, and V. A. Place. Transdermal drug delivery device. US Patent 4,725,439 (1988).

54. S. G. Korenman, S. Viosca, D. Garza, M. Guralnik, V. Place, P. Campbell, and S. S. Davis. Androgen therapy of hypogonadal men with transcrotal testosterone systems. Am. J. Med. 83:471-478 (1987).

55. J. C. Findlay, V. A. Place, and P. J. Snyder. Transdermal delivery of testosterone. J. Clin. Endocrinol. Metab. 64:266-268 (1987).

56. H. M. Behre, S. von Eckardstein, S. S. Kliesch, and E. Nieschlag. Long-term substitution therapy of hypogonadal men with transscrotal testosterone over 7-10 years. Clin. Endocrinol. (Oxf.) 50:629-635 (1999).

57. P. J. Snyder, H. Peachey, J. A. Berlin, P. Hannoush, G. Haddad, A. Dlewati, J. Santanna, L. Loh, D. A. Lenrow, J. H. Holmes, S. C. Kapoor, L. E. Atkinson, and B. L. Strom. Effects of testosterone replacement in hypogonadal men. J. Clin. Endocrinol. Metab. 85:2670-2677 (2000).

58. P. J. Snyder, H. Peachey, J. A. Berlin, D. Rader, D. Usher, L. Loh, P. Hannoush, A. Dlewati, J. H. Homes, J. Santanna, and B. Strom. Effect of transdermal testosterone treatment on serum lipid and apolipoprotein levels in men more than 65 years of age. Am. J. Med. 111:255-260 (2001).

59. C. J. Bagatell, R. J. Knopp, W. W. Vale, J. E. Rivier, and W. J. Bremner. Physiologic testosterone levels in normal men suppress high-density lipoprotein cholesterol levels. Ann. Intern. Med. 116:967-973 (1992).

60. J. C. Findlay, V. A. Place, and P. J. Snyder. Treatment of primary hypogonadism in men by the transdermal administration of testosterone. J. Clin. Endocrinol. Metab. 68:369-373 (1989).

61. M. Bals-Pratsch, U. A. Knuth, Y. D. Yoon, and E. Nieschlag. Transdermal testosterone substitution therapy for male hypogonadism. Lancet 2:943-946 (1986).

62. Z. Yu, S. K. Gupta, S. S. Hwang, M. S. Kipnes, A. D. Mooradian, P. J. Snyder, and L. E. Atkinson. Testosterone pharmacokinetics after application of an investigational transdermal system in hypogonadal men. J. Clin. Pharmacol. 37:1139-1145 (1997).

63. Z. Yu, S. K. Gupta, S. S. Hwang, D. M. Cook, M. J. Duckett, and L. E. Atkinson. Transdermal testosterone administration in hypogonadal men: comparison of pharmacokinetics at different sites of application and at the first and fifth days of application. J. Clin. Pharmacol. 37:1129-1138 (1997).

64. W. A. Meikle, S. Arver, A. S. Dobs, S. W. Sanders, L. Rajaram, and N. A. Mazer. Pharmacokinetics and metabolism of a permeation-enhanced testosterone transdermal system in hypogonadal men: influence of application site-a clinical research center study. J. Clin. Endocrinol. Metab. 81:1832-1840 (1996).

65. N. A. Mazer. Enhanced transdermal delivery of testosterone using the Theraderm ${ }^{\mathrm{TM}}$ TDS. In D. J. A. Crommelin and K. K. Midha (eds.), Topics in Pharmaceutical Sciences 1991, Medpharm Scientific Publishers, Stuttgart, 1992, pp. 149-170.

66. Androderm ${ }^{\circledR}$ CIII. Physicians Desk Reference, 53rd ed., Medical Economics Co, Montvale, NJ, 1999.

67. D. E. Wilson, W. A. Meikle, S. C. Boike, A. J. Fairless, R. C. Etheredge, and D. K. Jorkarsky. Bioequivalence assessment of a single $5 \mathrm{mg} /$ day testosterone transdermal system versus two $2.5 \mathrm{mg} /$ day systems in hypogonadal men. J. Clin. Pharmacol. 38:54-59 (1998).

68. S. Arver, A. S. Dobs, W. A. Meikle, K. E. Caramelli, L. Rajaram, S. W. Sanders, and N. A. Mazer. Long-term efficacy and safety of a permeation-enhanced testosterone transdermal system in hypogonadal men. Clin. Endocrinol. (Oxf.) 47: 727-737 (1997).

69. S. Arver, A. S. Dobs, W. A. Meikle, R. P. Allen, S. W. Sanders, and N. A. Mazer. Improvement of sexual function in testosterone deficient men treated for 1 year with a permeation enhanced testosterone transdermal system. J. Urol. 155:1604-1608 (1996).

70. A. S. Dobs, W. A. Meikle, S. Arver, S. W. Sanders, K. E. Caramelli, and N. A. Mazer. Pharmacokinetics, efficacy and safety of a permeation-enhanced testosterone transdermal system in comparison with bi-weekly injections of testosterone enanthate for the treatment of hypogonadal men. J. Clin Endocrinol. Metab. 84:3469-3478 (1999).

71. N. J. Bennett. A burn-like lesion caused by a testosterone transdermal system. Burns 24:478-480 (1998)

72. S. Bhasin, T. W. Storer, N. Asbel-Sethi, A. Kilbourne, R. Hays, I. Sinha-Hikim, R. Shen, S. Arver, and G. Beall. Effects of testosterone replacement with a non-genital transdermal system, Androderm ${ }^{\mathbb{B}}$, in human immunodeficiency virus-infected men with low testosterone levels. J. Clin. Endocrinol. Metab. 83:3155-3162 (1998).

73. S. Bhasin and W. J. Bremner. Clinical review 85: emerging issues in androgen replacement therapy. J. Clin. Endocrinol. Metab. 82:3-8 (1997)

74. V. De Sanctis, C. Vullo, L. Urso, F. Rigolin, A. Cavallini, K. E. Caramelli, C. Daugherty, and N. A. Mazer. Clinical experience using the Androderm testosterone transdermal system in hypogonadal adolescents and young men with $\beta$-thalassemia major. J. Pediatr. Endocrinol. Metab. 11:891-900 (1998).

75. A. W. Meikle. A permeation-enhanced non-scrotal testosterone transdermal system for the treatment of male hypogonadism. In E. Nieschlag and H. M. Behre (eds.), Testosterone-Action, Deficiency, Substitution, 2nd ed., SpringerVerlag, Berlin, 1998, pp. $389-422$

76. W. P. Jordan and L. E. Atkinson. Comparison of the skin irritation potential of two testosterone transdermal systems: an investigational system and a marketed product. Clin. Ther. 20: 80-87 (1998).

77. D. E. Wilson, K. Kaidbey, S. C. Boike, and D. K. Jorkasky. Use of topical corticosterol pre-treatment to reduce the incidence and severity of skin reactions associated with testosterone transdermal delivery. Clin. Ther. 20:299-306 (1998).

78. C. Wang, N. Berman, J. A. Longstreth, B. Chuapoco, L. Hull, B. Steiner, S. Faulkner, R. E. Dudley, and R. S. Swerdloff. Pharmacokinetics of transdermal testosterone gel in hypogonadal men: application of gel at one site versus four sites-a general clinical research center study. J. Clin. Endocrinol. Metab. 85:964-969 (2000).

79. C. Wang, R. S. Swerdloff, A. Iranmanesh, A. Dobs, P. J. Snyder, G. Cunningham, A. M. Matsumoto, T. Weber, and N Berman. Transdermal testosterone gel improves sexual function, mood, muscle strength, and body composition parameters in 
hypogonadal men. J. Clin. Endocrinol. Metab. 85:2839-2853 (2000).

80. C. Wang, R. S. Swerdloff, A. Iranmanesh, A. Dobs, P. J Snyder, G. Cunningham, A. M. Matsumoto, T. Weber, and N. Berman. Effects of transdermal testosterone gel on bone turnover markers and bone mineral density in hypogonadal men. Clin. Endocrinol. (Oxf.) 54:739-750 (2001).

81. T. Marbury, E. Hamill, R. Bachand, T. Sebree, and T. Smith. Evaluation of the pharmacokinetic profiles of the new testosterone topical gel formulation, Testim ${ }^{\mathrm{TM}}$, compared to Androgel ${ }^{\mathbb{R}}$. Biopharm. Drug Dispos. 24:115-120 (2003).

82. C. Steidle, S. Schwartz, K. Jacoby, T. Sebree, T. Smith, and R. Bachand. AA2500 testosterone gel normalizes androgen levels in aging males with improvements in body composition and sexual function. J. Clin. Endocrinol. Metab. 88:2673-2681 (2003).

83. G. Schaison, and B. Couzinet. Percutaneous dihydrotestosterone treatment. In E. Nieschlag and H. M. Behre (eds.), Testosterone-Action, Deficiency, Substitution, 2nd ed., Springer-Verlag, Berlin, 1998, pp. 329-348.

84. C. Rolf, S. Kemper, G. Lemmnitz, U. Eickenberg, and E. Nieschlag. Pharmacokinetics of a new transdermal testosterone gel in gonadotropin-suppressed normal men. Eur. J. Endocrinol. 146:673-679 (2002).

85. C. Rolf, U. Knie, G. Lemmnitz, and E. Nieschlag. Interpersonal testosterone transfer after topical application of a newly developed testosterone gel preparation. Clin. Endocrinol. (Oxf.) 56:637-641 (2002).

86. D. J. Kesler, D. C. Christenson, and M. E. Wallace. The effect of esterification on their release of testosterone and estradiol from silicone implants. Drug Dev. Ind. Pharm. 22:275-279 (1996).

87. B. Salehian, C. Wand, G. Alexander, T. Davidson, V. McDonald, N. Berman, R. E. Dudley, F. Zikl, and R. S. Verdloff. Pharmacokinetics, bioefficacy and safety of sublingual testosterone cyclodextrin in hypogonadal men: comparison to testosterone enanthate- a clinical research center study. J. Clin. Endocrinol. Metab. 80:3567-3575 (1995).

88. T. M. Morgan, B. L. Reed, and B. C. Finnin. Enhanced skin permeation of sex hormones with novel topical spray vehicles. J. Pharm. Sci. 87:1213-1218 (1998).

89. T. M. Morgan, R. A. Parr, B. L. Reed, and B. C. Finnin Enhanced transdermal delivery of sex hormones in swine with a novel topical aerosol. J. Pharm. Sci. 87:1219-1225 (1998).

90. E. Nieschlag, D. Buchter, S. von Eckardstein, K. Abshagen, M. Simoni, and H. M. Behre. Repeated intramuscular injections of testosterone undecanoate for substitution therapy in hypogonadal men. Clin. Endocrinol. (Oxf.) 51:757-763 (1999).

91. H. M. Behre and E. Nieschlag. Testosterone buciclate (20 Aet-1) in hypogonadal men: pharmacokinetics, and pharmacodynamics of the new long-acting androgen ester. J. Clin. Endocrinol. Metab. 75:1204-1210 (1992).

92. C. J. Partsch, G. F. Weinbauer, R. Fang, and E. Nieschlag. Injectable testosterone undecanoate has more favourable pharmacokinetics and pharmacodynamics than testosterone enanthate. Eur. J. Endocrinol. 132:514-519 (1995).

93. H. M. Behre, K. Abshagen, M. Oettel, D. Hübler, and E. Nieschlag. Intramuscular injection of testosterone undecanoate for the treatment of male hypogonadism: phase I studies. Eur. J. Endocrinol. 140:414-419 (1999).

94. G. F. Weinbauer, G. R. Marshall, and E. Nieschlag. New injectable testosterone ester maintains serum testosterone of castrated monkeys in the normal range for four months. Acta Endocrinol. 113:128-132 (1986).

95. H. M. Behre, S. Baus, S. Kliesch, C. Keck, M. Simoni, and E. Nieschlag. Potential of testosterone buciclate for male contraception: endocrine differences between responders and nonresponders. J. Clin. Endocrinol. Metab. 80:2394-2403 (1995).

96. A. S. Burris, L. L. Ewing, and R. J. Sherings. Initial trial of slow-release testosterone microspheres in hypogonadal men. Fertil. Steril. 50:493-497 (1988).
97. S. Bhasin, R. S. Swerdloff, B. Steiner, M. A. Peterson, T. Meridores, M. Galmirini, M. R. Pandian, R. Goldberg, and N. Berman. A biodegradable testosterone microcapsule formulation provides uniform eugonadal levels of testosterone for 10-11 weeks in hypogonadal men. J. Clin. Endocrinol. Metab. 74:75-83 (1992).

98. C. Danner and J. Frick. Androgen substitution with testosterone containing nasal drops. Int. J. Androl. 3:429-435 (1980).

99. A. A. Hussain, A. A Al-Bayatti, A. Dakkuri, K. Okochi, and M. A. Hussain. Testosterone $17 \beta-N, N$-dimethylglycinate hydrochloride: a prodrug with a potential for nasal delivery of testosterone. J. Pharm. Sci. 91:785-789 (2002).

100. K. T. Ko, T. E. Needham, and H. Zia. Emulsion formulations of testosterone for nasal administration. J. Microencapsul. 15:197-205 (1998).

101. D. A. Edwards, J. Hanes, G. Caponetti, J. Hrkach, A. BenJebria, A. L. Eskew, J. Mintzes, D. Deaver, N. Lotan, and R. Langer. Large porous particles for pulmonary drug delivery. Science 276:1868-1869 (1997).

102. L. Davison, J. Thipphawong, J. Blanchard, K. Liu, R. Morishige, I. Gonda, J. Okikawa, J. Adams, A. Evans and S. R. Davis. Pulsed testosterone therapy: pharmacokinetics and safety of inhaled testosterone in postmenopausal women. 10th World Congress on the Menopause, Berlin, June 2002.

103. J. Voorspoels, J. P. Remon, W. Eechaute, and W. De Sy. Buccal absorption of testosterone and its esters using a bioadhesive tablet in dogs. Pharm. Res. 13:1228-1231 (1996).

104. S. Jay, W. Foutain, Z. Cui, and R. J. Mumper. Transmucosal delivery of testosterone in rabbits using novel bi-layer mucoadhesive wax-film composite disks. J. Pharm. Sci. 91:2016-2025 (2002).

105. A. Dobs, D. R. Hoover, M. C. Chen, and R. Allen. Pharmacokinetic characteristics, efficacy, and safety of buccal testosterone in hypogonadal males: a pilot study. J. Clin. Endocrinol. Metab. 83:33-39 (1998).

106. K. J. Baisley, M. J. Boyce, S. Bukofzer, R. Pradham, and S. J. Warrington. Pharmacokinetics, safety and tolerability of three dosage regimens of buccal adhesive testosterone tablets in healthy men suppressed with leuprorelin. J. Endocrinol. 175:813-819 (2002).

107. M. K. Kim, C. H. Lee, and D. D. Kim. Skin permeation of testosterone and its ester derivatives. J. Pharm. Pharmacol. 52:369-375 (2000).

108. M. K. Kim, H. Zhao, C. H. Lee, and D. D. Kim. Formulation of a reservoir-type testosterone transdermal delivery system. Int. J. Pharm. 219:51-59 (2001).

109. N. M. An, D. D. Kim, Y. H. Shin, and C. H. Lee. Development of a novel soft hydrogel for the transdermal delivery of testosterone. Drug Dev. Ind. Pharm. 29:99-105 (2003).

110. C. M. Samour and S. Daskalakis. Percutaneous absorption enhancers, compositions containing same method of use. US Patent 4,861,764 (1989).

111. http://www.macrochem.com/site/content/products/hormone.asp (accessed 11/20/04).

112. B. C. Finnin, J. Hadgraft, K. Klose and A. Humberstone. Prediction of plasma concentrations for an estradiol metered dose transdermal spray $\left(\mathrm{MDTS}^{\circledR}\right)$. Controlled Release Society 30th Annual Meeting, \#855, 2003.

113. N. Chew, K. Klose and B. Thomas. Transdermal drug delivery of granisetron using MDTS $^{\circledR}$ technology. Controlled Release Society 30th Annual Meeting, \#849, 2003.

114. A. Joshi, and J. Raje. Sonicated transdermal transport. $J$. Control. Release 83:13-22 (2002).

115. N. N. Byl. The use of ultrasound as an enhancer for transcutaneous drug delivery: phonophoresis. Phys. Ther. 75:539-553 (1995).

116. S. Mitragotri. Low frequency sonophoresis: a non-invasive method of drug delivery and diagnostics. Biotechnol. Prog. 16: $488-492$ (2000).

117. S. Mitragotri and J. Kost. Low frequency sonophoresis. $A d v$. Drug Deliv. Rev. 56:589-601 (2004).

118. J. P. Simonin. On the mechanisms of in vitro and in vivo phonophoresis. J. Control. Release 33:125-141 (1995). 